\title{
Processo Orçamentário e Comportamento Legislativo: Emendas Individuais, Apoio ao Executivo e Programas de Governo*
}

\author{
Fernando Limongi \\ Argelina Figueiredo
}

\section{INTRODUÇÃO}

N as análises das relações entre o Executivo e o Legislativo, a prerdestaque. Essa prerrogativa resumir-se-ia, a se crer nessas análises, às emendas individuais. Não é difícil compreender a atração que esse aspecto do processo orçamentário exerce sobre os analistas: as emendas individuais permitem resgatar elementos cruciais das interpretações correntes acerca do modus operandi do sistema político brasileiro. Forneceriam, sobretudo, as evidências necessárias de que esse sistema se alicerça no individualismo dos políticos, dando lugar a uma distribuição clientelística e localista dos recursos públicos.

Essas emendas seriam as engrenagens centrais de um complexo sistema de trocas de apoio que garantiria, na arena legislativa, o apoio "da

\footnotetext{
${ }^{*} \mathrm{O}$ texto que deu origem a este artigo foi preparado para o $4^{\circ}$ Encontro Nacional da Associação Brasileira de Ciência Política, realizado no Rio de Janeiro, de 21 a 24 de julho de 2004. As modificações feitas posteriormente se beneficiaram de comentários do debatedor, Octavio Amorim Neto, e dos participantes da reunião em que foi apresentado naquela ocasião, assim como dos pareceristas da revista Dados. Este trabalho, que conta com o financiamento da Fundação Konrad Adenauer e da Fundação de Amparo à Pesquisa do Estado de São Paulo - FAPESP, é parte de um livro em elaboração que trata da participação do Congresso no processo orçamentário. Queremos deixar claro que se trata do estudo de um aspecto específico de um processo mais amplo e complexo cujo tratamento não pode ser feito nos limites de um artigo.
}

DADOS - Revista de Ciências Sociais, Rio de Janeiro, Vol. 48, n-4, 2005, pp. 737 a 776. 
base do governo" ao Executivo e, na arena eleitoral, os recursos que os deputados carreariam para as suas bases eleitorais. A execução das emendas individuais seria a "moeda de troca" a selar acordos que envolveriam eleitores, legisladores e Executivo. Nesses termos, a incorporação das emendas individuais à análise tem sido vista como o "elo perdido" que permitiria reunir em um único corpo analítico a arena eleitoral e a legislativa.

No que se refere à arena eleitoral, o argumento baseia-se naquela que seria a necessidade básica de todo e qualquer político: encontrar os meios necessários a fim de garantir sua reeleição. Para tanto, de acordo com a cartilha vigente, existiria uma estratégia que garantiria aos políticos maior retorno eleitoral, qual seja, a de levar benefícios tangíveis a redutos claramente definidos. O eleitor, em reconhecimento ou, melhor dizendo, como pagamento aos serviços prestados, retribuiria com seu voto. Dito de outra maneira, as emendas individuais ao orçamento seriam usadas como parte de uma estratégia eleitoral identificada pela literatura especializada como "voto pessoal" (Cain, Ferejohn e Fiorina, 1987). A "conexão eleitoral" - para usar outro termo em voga - à brasileira dependeria da execução dessas emendas ${ }^{1}$. Na realidade, as referências aos modismos correntes na ciência política norte-americana são dispensáveis. A visão folclórica e caricata de nossos políticos não é outra: individualistas e interessados tão-somente em obter votos, sacrificariam, para tanto, o bem público.

No que tange à arena legislativa, o ponto de partida do argumento é a separação de poderes própria ao presidencialismo, e a conseqüência usualmente derivada dele, qual seja, a ausência de mecanismos - em contraste com o que ocorreria no parlamentarismo - que garantam ao chefe do Executivo o apoio político à sua agenda legislativa. O Executivo precisa de votos dos parlamentares, mas não disporia dos meios para obtê-los. Já os primeiros-ministros obteriam esse apoio por meio da ameaça de dissolução do Parlamento e da antecipação das eleições, o que colocaria em risco os mandatos dos legisladores. No entanto, como o presidente controla a execução orçamentária, o Executivo poderia trocar os recursos que os parlamentares querem levar às suas bases eleitorais pelos votos que necessita para aprovar sua agenda. A liberação de recursos do orçamento, portanto, seria o meio utilizado pelo Executivo para obter o apoio dos parlamentares. 
A relação entre a liberação de recursos para execução das dotações previstas nas emendas individuais e o apoio ao Executivo em votações nominais é sugerida com insistência pela imprensa e por parte da comunidade acadêmica. Em 27 de novembro de 2003, dia em que este texto começou a ser redigido, a manchete de $O$ Estado de $S$. Paulo relativa à aprovação, pelo Senado, da reforma tributária encaminhada pelo governo informava que os parlamentares receberiam a sua contrapartida, pois, tendo atendido as pretensões do governo, solicitariam como recompensa a liberação de recursos públicos para atender às demandas das suas clientelas eleitorais.

As análises acadêmicas não divergem dessa visão. Para Santos et alii (1997):

“No jogo orçamentário [...] identificam-se claramente duas lógicas distintas: a do Executivo, cujas ações são voltadas para a aprovação dos projetos na agenda governamental e, no atual contexto de estabilização da economia, para o corte de gastos; e a do Legislativo, a quem interessa em primeiro lugar a maximização dos ganhos eleitorais de seus membros, dirigindo suas ações, apenas secundariamente, para a aprovação de projetos que, encarnando o bem público, não trariam ganhos individuais imediatos. [...] [Na fase de apreciação da proposta do Executivo] predomina no jogo a lógica do Legislativo, obrigando o Executivo a negociar na $\mathrm{CMO}$ os projetos de seu interesse.

Na fase da execução orçamentária, entretanto, o Executivo vira o jogo. [...] mesmo decidindo em última instância sobre o conflito distributivo, o Executivo não é o soberano absoluto, obrigado que é a negociar os vetos, os cortes, os créditos adicionais em troca de apoio parlamentar às políticas prioritárias da agenda governamental." (idem:118-119)

Segundo Pereira e Mueller (2002), a execução das emendas individuais é "um dos mecanismos mais importantes de que o Executivo dispõe para negociar suas preferências com sua coalizão no Congresso". $O$ controle do processo orçamentário pelo Executivo acaba por dotá-lo de uma "'moeda' política de baixo custo e extremamente útil para ser trocada por apoio político da sua coalizão no Congresso" (idem:267). Para esses autores:

"As evidências apresentadas [...] demonstram que o presidente da República recompensa os parlamentares que sistematicamente votam a favor dos projetos de interesse do governo, autorizando a execução de suas emendas individuais, e, ao mesmo tempo, pune os que não votam 
nesses projetos simplesmente não executando as emendas propostas por eles" (idem:274).

Neste artigo, procuramos discutir esses argumentos examinando não só os aspectos empíricos envolvidos, mas também as suas suposições teóricas. Em primeiro lugar, cabe ressaltar que, qualquer que seja o prisma através do qual sejam vistas, as emendas individuais estão longe de ser o meio mais importante de participação do Congresso no processo orçamentário. Isso porque, além das emendas individuais, o Congresso pode apresentar dois outros tipos de emendas: as coletivas - que podem ser apresentadas por bancadas estaduais e regionais ou por comissões - e as dos relatores, que podem ser de autoria do relator geral ou dos relatores parciais. As emendas individuais também não são privilegiadas pelo próprio Legislativo, pois, em termos de recursos alocados, as emendas coletivas e as de relatores têm precedência sobre as individuais. Como a definição do volume de recursos para as emendas individuais é uma decisão interna do Poder Legislativo, tal constatação é suficiente para colocar sob suspeição a noção de que o processo orçamentário é orientado exclusivamente para atender os interesses individuais dos parlamentares.

Porém, a despeito dessa suspeição, dado o papel que normalmente se atribui à liberação de recursos por meio de emendas individuais nas relações entre Executivo e Legislativo, examinamos a fundo a tese de que votos seriam trocados por execução de emendas, mostrando que não é possível estabelecer a relação causal pretendida. Para tanto, analisamos a aprovação e a execução das emendas individuais no período de 1996 a 2001². Emendas são executadas sem que os votos esperados sejam dados, e votos são dados sem que a contrapartida - ou seja, a liberação de recursos - ocorra. Há casos, inclusive, em que, dada a rotatividade dos membros do Legislativo, a troca de votos pela execução de emendas sequer seria possível. Há um sem-número de deputados que votam a favor dos interesses do Executivo sem participarem do processo orçamentário, e há os que participam e têm suas emendas executadas apesar de não mais exercerem mandatos.

Discutimos ainda os supostos comportamentais envolvidos. A tese de que as emendas são "moedas de troca" pressupõe que os legisladores têm um interesse comum, qual seja, o da promoção de políticas distributivistas. Políticas desse tipo são tidas como as mais apropriadas para aumentar as chances de que os parlamentares obtenham sua tão alme- 
jada reeleição. Implicitamente, as emendas individuais são tomadas como contrárias aos interesses do Executivo, entendendo-se que, se este contasse com total liberdade para alocar recursos, não patrocinaria as políticas defendidas pelos parlamentares. De acordo com este argumento, quando o presidente executa recursos alocados por emendas individuais, o faz às expensas de suas próprias prioridades. No que tange à alocação de recursos públicos, as relações entre o Executivo e o Legislativo seriam caracterizadas por um jogo de soma zero.

Mostramos que tal visão desconsidera a realidade partidária que divide os parlamentares entre os que apóiam e os que se opõem ao governo. Do ponto de vista político, essa determinação é anterior e mais ampla do que a participação no processo orçamentário e a execução das emendas individuais. No que se refere especificamente ao orçamento, essa relação implica, em primeiro lugar, a aceitação da centralização da condução do processo orçamentário na sua fase congressual. Há uma delegação de poder das bases para as lideranças partidárias, representadas, nesse caso, pelo relator geral e seus colaboradores diretos ( $\mathrm{Fi}$ gueiredo e Limongi, 2002; 2003).

Quanto às prioridades de um e outro poder expressas na alocação de recursos orçamentários, mostramos que as diferenças são muito pequenas. Ou seja, não há agendas conflitantes. Mais especificamente, ao executar recursos alocados pelos parlamentares por meio de emendas individuais, o Executivo não está cedendo a pressões e deixando de executar a sua agenda. A alocação de recursos feita pelos legisladores é complementar, e não contrária, à do Executivo. Isso porque o controle que o Executivo detém sobre o processo orçamentário é maior do que usualmente se supõe. O Executivo é capaz de canalizar as demandas dos parlamentares e acomodá-las no interior do seu programa. Por isso mesmo, executa também emendas de parlamentares da oposição e/ou da situação que não votam segundo os interesses do governo.

\section{EXECUÇÃO ORÇAMENTÁRIA E APOIO AO EXECUTIVO}

As emendas individuais são apenas uma das formas pelas quais os congressistas alteram a proposta orçamentária preparada pelo Executivo. As resoluções do Congresso Nacional que regulamentam a participação dos parlamentares no processo orçamentário - isto é, os regulamentos internos da Comissão Mista de Planos, Orçamento e Fiscali- 
zação - $\mathrm{CMPOF}^{3}$ - prevêem ainda emendas coletivas e emendas dos relatores.

O peso relativo das emendas individuais em relação ao total de recursos alocados pelo Legislativo é pequeno. No período considerado, a participação das emendas individuais no total das emendas aprovadas pelo Congresso foi de 17,4\%. Dito em reverso, para enfatizar o ponto: $82,6 \%$ dos recursos alocados pelo Congresso para investimentos são fruto de emendas coletivas ou de atores institucionais (relatores). E essa é uma decisão que foi tomada pelos congressistas. Do total de recursos que aloca do orçamento, o Congresso optou por reservar a maior parte para as emendas coletivas. Não é fácil compatibilizar tal fato com a ênfase que normalmente se atribui ao "voto pessoal" e ao individualismo dos políticos brasileiros. Se as emendas individuais são tão importantes para a reeleição, por que destinar a "parte do leão" para os outros tipos de emendas?

Cabe observar ainda que o Executivo, quando da liquidação do orçamento, também não dá prioridade às emendas individuais dos parlamentares. As emendas individuais são as que têm menor taxa de execução: a média do período é de $59,6 \%$, contrastando com os $78 \%$ executados das emendas propostas por comissões, os $62,2 \%$ das emendas apresentadas pelas bancadas estaduais e os $65,4 \%$ das emendas do relator geral. Se os parlamentares tivessem o poder de barganha que a eles se atribui, deveriam obter maiores concessões do que de fato obtêm. E se as emendas individuais são tão decisivas para suas carreiras políticas, por que não se rebelam contra as baixas taxas de execução? $\mathrm{Ou}$, argumentando em outro sentido, se o governo tivesse a dificuldade usualmente alegada para arregimentar e garantir apoio à sua agenda seria de esperar, então, que dispensasse maior atenção às demandas individuais dos parlamentares.

Em suma, quer olhemos para as alocações feitas pelo Congresso, quer para as decisões do Executivo quando liquida os gastos alocados pelo Legislativo, não encontramos respaldo para a suposição de que as emendas individuais ocupam posição central nesse processo. Nas duas pontas do processo, as emendas coletivas e aquelas apresentadas pelos relatores são priorizadas. No entanto, ainda que esses números sejam públicos e conhecidos, a opinião pública, a imprensa e os cientistas políticos consideram as emendas individuais como os eixos centrais sobre os quais se estrutura o processo orçamentário. Essas interpreta- 
ções baseiam-se em concepções teóricas e premissas equivocadas sobre a lógica do funcionamento do sistema político brasileiro, o que mostraremos adiante.

Dada a importância que lhes é geralmente conferida, deixaremos de lado as demais emendas e nos concentraremos apenas nas emendas individuais. Nosso objetivo é mostrar que, mesmo quando tratadas isoladamente -isto é, quando se abstrai o restante do processo orçamentário-, ainda assim a execução das emendas individuais não permite que essas sejam caracterizadas como moeda pela qual o apoio parlamentar é obtido.

A partir de 1995, o regulamento interno da Comissão Mista do Orçamento - CMO definiu os tetos para as emendas individuais, fixando tanto o número máximo de emendas a serem apresentadas por cada parlamentar, como também o valor total máximo para as emendas aprovadas por cada parlamentar. Assim, quanto a esse aspecto, não há distinção entre os parlamentares. Ao longo de todo o período, o número de emendas permitido por cada parlamentar foi de 20 emendas anuais. Quanto aos valores aprovados, o teto estabelecido variou com o tempo. Entre 1996 e 1999, foi de R \$ 1,5 milhão, passando a R \$ 2,0 milhões em 2000. No orçamento de 2001, esse valor foi novamente corrigido, passando para 2,5 milhões ${ }^{4}$. Isso significa que, tomado individualmente, cada parlamentar tem a mesma capacidade de influir na alocação final dos recursos orçamentários. O partido ao qual é filiado, o número de mandatos exercidos, a posição na hierarquia interna do Poder Legislativo, a região ou o estado de origem, os vínculos com o Executivo, enfim, nenhuma característica do parlamentar afeta a sua capacidade de alocar recursos.

Como os recursos são distribuídos de maneira uniforme, não cabe investigar que grupo de parlamentares, qualquer que seja a sua natureza, perde ou ganha com a alocação feita. A regra adotada para a distribuição de recursos neutraliza a influência de qualquer outro fator que distinga politicamente os parlamentares. Assim, não faz qualquer sentido falar em log-roll entre parlamentares para a aprovação de emendas. Não há apoios ou interesses a trocar. Cada um tem seu quinhão assegurado de antemão e não precisa dos votos dos demais para ter seus interesses atendidos. A norma adotada é a do universalismo, garantido por força dos preceitos estabelecidos pelo parecer preliminar elaborado pelo relator geral. 
Deve ser observado que a adoção dessa regra tem implicações nas relações dos parlamentares entre si e deles com os relatores. Todos são tratados como iguais, fato que neutraliza ou pelo menos diminui o grau de conflito que o acesso a recursos escassos ocasiona. Pelo que se conhece do processo orçamentário, antes da adoção dessa regra a divisão de recursos entre os parlamentares era bastante desigual, favorecendo aqueles subgrupos de parlamentares que tinham acesso privilegiado às instâncias de poder no interior do próprio processo orçamentário. Com isso, ganhava o grupo que gravitava em torno dos parlamentares que controlavam as relatorias do orçamento, e que vieram a ser conhecidos como os "anões do orçamento".

A divisão uniforme dos recursos pelos parlamentares deve ser entendida, então, como um dos capítulos da racionalização da participação legislativa no processo orçamentário, racionalização que conferiu às relatorias um papel mais institucional, colocando-as sob maior controle das lideranças partidárias e garantindo, assim, a prevalência dos interesses da coalizão majoritária que apóia o Executivo. Ao assegurar a distribuição uniforme dos recursos pelos parlamentares, o trabalho do relator geral ganha maior liberdade, na medida em que se vê livre da necessidade de arbitrar a disputa interna por verbas. Dessa forma, o princípio adotado reduz os custos da aprovação da proposta encaminhada pelo relator.

Na realidade, o conflito interno é transferido para um outro momento do ciclo orçamentário, o da execução das dotações. Na aprovação, a distribuição de recursos é uniforme, mas a execução não obedece à mesma regra. Isto é, o Executivo, que conta com ampla margem de liberdade para executar o orçamento, sobretudo no que se refere aos gastos alocados para investimentos, diferencia - ou pode diferenciar - os parlamentares. Por isso, a execução está longe de resguardar a distribuição de recursos feita pelo Legislativo.

Há uma diferença profunda na participação dos parlamentares no que diz respeito à aprovação e à execução de recursos. A Tabela 1 mostra que as taxas individuais de execução das emendas parlamentares apresentam variação significativa ${ }^{5}$. Por exemplo, no orçamento de 1996, dos 444 parlamentares que tiveram recursos alocados em investimentos por meio de emendas individuais, 20,3\% deles foram contemplados com uma execução inferior a 10\%. Nesse mesmo ano, no outro extremo da distribuição, somente oito parlamentares $(1,8 \%$ dos parla- 
mentares com emendas aprovadas) tiveram o valor integral de suas emendas executadas pelo Executivo. Vê-se, assim, que a execução, ao contrário da aprovação, discrimina os parlamentares.

Tabela 1

Percentual de Deputados por Taxas de Execução das Emendas Individuais (Decis) em Investimentos

1996-2001

\begin{tabular}{l|c|c|c|c|c|c}
\hline \multirow{2}{*}{$\begin{array}{l}\text { Taxa de Execução } \\
\text { de Emendas* }\end{array}$} & \multicolumn{6}{|c}{ Percentual de Deputados } \\
\cline { 2 - 7 }$\%$ & $\mathbf{1 9 9 6}$ & $\mathbf{1 9 9 7}$ & $\mathbf{1 9 9 8}$ & $\mathbf{1 9 9 9}$ & $\mathbf{2 0 0 0}$ & $\mathbf{2 0 0 1}$ \\
\hline 0 a 10 & 20,3 & 2,4 & 9,7 & 3,4 & 3,0 & 1,8 \\
10 a 20 & 13,3 & 3,5 & 9,7 & 3,2 & 4,9 & 1,4 \\
20 a 30 & 11,5 & 5,7 & 9,0 & 5,8 & 5,3 & 2,4 \\
30 a 40 & 9,2 & 7,7 & 7,1 & 6,4 & 8,1 & 5,3 \\
40 a 50 & 10,1 & 9,0 & 12,0 & 8,2 & 9,7 & 6,9 \\
50 a 60 & 10,4 & 13,4 & 14,0 & 12,6 & 10,7 & 8,7 \\
60 a 70 & 8,6 & 11,6 & 17,4 & 14,4 & 15,4 & 11,0 \\
70 a 80 & 8,1 & 15,7 & 14,0 & 11,6 & 17,9 & 17,6 \\
80 a 90 & 3,8 & 16,5 & 6,0 & 19,2 & 13,4 & 21,3 \\
90 a 100 & 2,9 & 13,2 & 1,1 & 13,4 & 10,1 & 20,3 \\
100 & 1,8 & 1,2 & 0,0 & 2,0 & 1,6 & 3,4 \\
\hline Taxa Média & 38,3 & 63,4 & 47,1 & 63,9 & 61,4 & 71,9 \\
\hline № de Deputados & 444 & 491 & 465 & 501 & 507 & 507 \\
\hline
\end{tabular}

Fontes: Assessoria de Orçamento e Fiscalização Financeira da Câmara dos Deputados, Banco de Dados Legislativos, Centro Brasileiro de Análise e Planejamento - Cebrap.

* O cálculo da taxa de execução é feito levando-se em consideração o valor das emendas executadas sobre o valor das emendas aprovadas e compreende o total de emendas individuais referentes a investimentos apresentados e liquidados.

A participação final dos parlamentares na alocação de recursos é bastante heterogênea, e essa heterogeneidade é decorrente das decisões tomadas pelo Poder Executivo ao contingenciar ou liberar os recursos alocados. Dados os amplos graus de liberdade deixados à discrição do Executivo, cabe indagar quais os critérios utilizados por esse Poder em suas decisões ${ }^{6}$. Cabe notar que a taxa média de execução variou ano a ano. O ano com a menor taxa de execução foi o de 1996, quando menos de $40 \%$ do valor das emendas individuais foram executados, e mais de $50 \%$ dos parlamentares tiveram menos do que $40 \%$ dos valores que definiram no orçamento executados. O ano de 1998 foi outro ano de recursos escassos para os parlamentares, enquanto 2001 foi o mais profí- 
cuo. Como argumentamos em outras oportunidades, acreditamos que essa variação anual da taxa de execução atende às necessidades da política econômica perseguida pelo Executivo e em nada depende, ou depende muito pouco, do poder de pressão dos parlamentares ${ }^{7}$.

Quando as taxas de execução são organizadas por grupos de partidos, como na Tabela 2, temos uma indicação de um dos critérios usados pelo Executivo para orientar suas decisões. Os parlamentares filiados a partidos de centro e de direita que apóiam o Executivo ${ }^{8}$ são beneficiados, ao passo que os de esquerda - os de oposição no período analisado - são prejudicados. A conclusão óbvia parece se impor: a execução das emendas individuais é ditada por critérios político-partidários.

Tabela 2

Taxas Médias de Execução* das Emendas Individuais em Investimentos, por Partido

1996-2001

\begin{tabular}{|c|c|c|c|c|c|c|}
\hline Partido & 1996 & 1997 & 1998 & 1999 & 2000 & 2001 \\
\hline \multicolumn{7}{|c|}{ Coalizão de governo } \\
\hline $\mathrm{PFL}^{* *}$ & 50,4 & 71,0 & 61,8 & 72,3 & 67,2 & 82,3 \\
\hline PMDB & 44,6 & 68,0 & 51,0 & 70,2 & 70,7 & 79,5 \\
\hline PPB & 38,5 & 59,5 & 43,3 & 61,2 & 66,8 & 76,3 \\
\hline PSDB & 45,2 & 70,8 & 53,5 & 68,1 & 72,8 & 79,1 \\
\hline PTB & 32,7 & 62,6 & 58,2 & 70,9 & 59,3 & 71,2 \\
\hline \multicolumn{7}{|l|}{ Direita } \\
\hline PL & 32,0 & 56,3 & 53,1 & 70,0 & 38,4 & 64,0 \\
\hline PSC & & 100,0 & & & & \\
\hline PSD & 23,1 & 64,9 & 66,5 & 65,8 & 64,0 & \\
\hline PSL & 19,1 & 77,9 & 46,1 & & 47,0 & 77,0 \\
\hline Prona & & & 43,8 & 42,7 & & \\
\hline PST & & & & & 62,2 & 59,1 \\
\hline PHS & & & & & 61,0 & 88,4 \\
\hline PTN & & & & & & 91,3 \\
\hline Sem Partido & 37,1 & 81,1 & & & 44,6 & \\
\hline \multicolumn{7}{|l|}{ Esquerda } \\
\hline PC do B & 17,7 & 39,7 & 17,4 & 47,2 & 30,3 & 41,5 \\
\hline PDT & 16,9 & 48,7 & 24,9 & 37,0 & 40,3 & 50,4 \\
\hline PMN & 17,9 & 46,5 & 21,4 & 67,6 & 48,0 & \\
\hline
\end{tabular}

** Ver lista de siglas com os respectivos significados ao final do artigo. 
Processo Orçamentário e Comportamento Legislativo...

Tabela 2

Taxas Médias de Execução* das Emendas Individuais em Investimentos, por Partido

1996-2001

(continuação)

\begin{tabular}{|c|c|c|c|c|c|c|}
\hline Partido & 1996 & 1997 & 1998 & 1999 & 2000 & 2001 \\
\hline PPS & & & 21,8 & 62,7 & 52,7 & 58,9 \\
\hline PSB & 10,3 & 57,2 & 21,5 & 65,1 & 37,1 & 50,3 \\
\hline PT & 15,5 & 44,0 & 15,3 & 39,1 & 31,1 & 45,9 \\
\hline PV & 5,0 & 42,3 & 0,0 & 55,1 & 99,9 & 73,1 \\
\hline PSTU & & & & 0,0 & & \\
\hline \multicolumn{7}{|c|}{ Subtotais } \\
\hline GOV & 44,1 & 67,1 & 53,4 & 68,6 & 69,0 & 79,1 \\
\hline DIR & 30,9 & 65,5 & 54,2 & 67,1 & 48,3 & 66,5 \\
\hline ESQ & 15,3 & 46,9 & 18,7 & 44,6 & 36,0 & 48,6 \\
\hline Total & 38,3 & 63,4 & 47,1 & 63,9 & 61,4 & 71,9 \\
\hline
\end{tabular}

Fontes: Assessoria de Orçamento e Fiscalização Financeira da Câmara dos Deputados, Banco de Dados Legislativos, Cebrap.

* O cálculo da taxa de execução é feito levando-se em consideração o valor das emendas executadas sobre o valor das emendas aprovadas e compreende o total de emendas individuais referentes a investimentos apresentados e liquidados.

O apoio à agenda do Executivo em votações nominais segue as bases partidárias de forma similar à captada na execução das emendas. Foram consideradas como parte da agenda do Executivo as votações de emendas constitucionais em que a posição do Executivo era conhecida. Trata-se de um critério mais exigente do que o normalmente utilizado e que permite um teste mais acurado das hipóteses em consideração. Como a aprovação das emendas constitucionais exige quórum qualificado, o voto dos parlamentares tem "maior valor" para o Executivo. As faltas nas votações foram tratadas como votos indisciplinados quando o Executivo indicou voto " $\mathrm{sim}^{\text {"9 }}$. Somente parlamentares que votaram mais de 10 vezes ao ano foram incluídos na análise. O número de votações consideradas variou a cada ano. Para manter a consistência nas análises que se seguem, a amostra incluiu apenas os parlamentares que emendaram o orçamento e que não migraram entre partidos da situação e oposição, ou vice-versa.

A Tabela 3 não deixa margem a dúvidas: a probabilidade de um deputado votar favoravelmente à agenda do governo está relacionada à sua filiação partidária. A taxa média de apoio de um membro da bancada da base do governo girou em torno de $75 \%$, variando por partidos ${ }^{10}$. Os 
deputados filiados ao PFL e ao PSDB tenderam a votar de forma mais coesa e consistente do que os parlamentares do PPB e PMDB. Nesses dois últimos partidos, em algumas matérias ou áreas, há alguns poucos deputados cujo comportamento se assemelha ao dos deputados de oposição, o que explica a queda nas médias.

Tabela 3

Percentual Médio de Apoio ao Executivo* por Partido - Votações Nominais de Emendas Constitucionais

1996-2001

\begin{tabular}{|c|c|c|c|c|c|c|c|}
\hline Partido/Ano & 1996 & 1997 & 1998 & 1999 & 2000 & 2001 & Média \\
\hline \multicolumn{8}{|c|}{ Coalizão de governo } \\
\hline PFL & 79,0 & 89,5 & 81,8 & 77,3 & 79,6 & 73,6 & 80,5 \\
\hline PMDB & 70,3 & 74,4 & 64,1 & 68,3 & 68,3 & 67,9 & 68,9 \\
\hline РPB & 71,1 & 71,3 & 63,0 & 70,7 & 79,7 & 77,3 & 71,4 \\
\hline PSDB & 80,3 & 86,2 & 79,9 & 77,4 & 84,5 & 75,9 & 81,1 \\
\hline РTB & 78,0 & 75,3 & 77,3 & 78,8 & 80,5 & 75,2 & 77,4 \\
\hline \multicolumn{8}{|l|}{ Direita } \\
\hline PL & 52,6 & 61,0 & 55,0 & 52,1 & 46,9 & 49,8 & 52,4 \\
\hline PSC & & & & & 59,3 & & 59,3 \\
\hline PSD & 74,0 & 73,9 & 65,9 & & & & 71,7 \\
\hline PSL & 79,6 & 73,9 & & & 21,1 & 31,8 & 38,9 \\
\hline Prona & & 92,6 & 90,9 & & & & 91,8 \\
\hline PST & & & & 53,1 & 46,4 & 50,0 & 48,7 \\
\hline PHS & & & & & 77,8 & 70,0 & 73,9 \\
\hline PTN & & & & 93,3 & 20,0 & 36,4 & 49,9 \\
\hline PSDC & & & & & & 9,1 & 9,1 \\
\hline Sem Partido & & & 65,8 & & 43,3 & & 52,3 \\
\hline \multicolumn{8}{|l|}{ Esquerda } \\
\hline PC do B & 21,2 & 4,2 & 0,0 & 24,4 & 18,6 & 7,8 & 11,9 \\
\hline PDT & 18,0 & 11,3 & 5,4 & 19,6 & 6,7 & 13,2 & 11,7 \\
\hline PMN & 3,7 & 29,6 & & & & & 16,7 \\
\hline PPS & & 53,1 & 14,5 & 81,3 & 30,7 & 26,4 & 31,9 \\
\hline PSB & 14,3 & 20,2 & 3,0 & 22,9 & 17,4 & 11,9 & 13,9 \\
\hline $\mathrm{PT}$ & 6,9 & 0,3 & 3,7 & 14,8 & 18,4 & 17,0 & 11,0 \\
\hline PV & 24,0 & 30,8 & 5,3 & 37,5 & 30,0 & 90,9 & 36,4 \\
\hline PSTU & & 0,0 & 4,8 & & & & 2,4 \\
\hline
\end{tabular}


Processo Orçamentário e Comportamento Legislativo...

Tabela 3

Percentual Médio de Apoio ao Executivo* por Partido - Votações Nominais de

Emendas Constitucionais

1996-2001

(continuação)

\begin{tabular}{l|c|c|c|c|c|c|c}
\hline Partido/Ano & $\mathbf{1 9 9 6}$ & $\mathbf{1 9 9 7}$ & $\mathbf{1 9 9 8}$ & $\mathbf{1 9 9 9}$ & $\mathbf{2 0 0 0}$ & $\mathbf{2 0 0 1}$ & Média \\
\hline Subtotais \\
\hline GOV & 75,3 & 80,7 & 72,0 & 74,8 & 77,7 & 73,7 & 75,8 \\
DIR & 65,8 & 70,8 & 62,6 & 52,3 & 39,2 & 41,9 & 54,0 \\
ESQ & 14,9 & 8,7 & 5,7 & 20,9 & 18,0 & 14,7 & 13,4 \\
\hline Total & $\mathbf{6 4 , 0}$ & $\mathbf{6 7 , 6}$ & $\mathbf{5 9 , 1}$ & $\mathbf{6 4 , 9}$ & $\mathbf{6 3 , 9}$ & $\mathbf{5 9 , 7}$ & $\mathbf{5 3 , 1}$ \\
\hline $\mathbf{N}$ & $\mathbf{2 9}$ & $\mathbf{3 1}$ & $\mathbf{4 5}$ & $\mathbf{2 5}$ & $\mathbf{4 1}$ & $\mathbf{1 7}$ & $\mathbf{1 8 8}$ \\
\hline
\end{tabular}

Fontes: Diário do Congresso Nacional, Banco de Dados Legislativos, Cebrap.

* Voto favorável a projetos de interesse do Executivo.

Observa-se, portanto, que há uma correlação entre a execução das emendas individuais e o comportamento nas votações nominais. A execução dos recursos alocados pelas emendas individuais ao orçamento favorece, justamente, os membros daqueles partidos que votam favoravelmente à agenda legislativa do Executivo. Há, assim, fortes indícios de que exista uma relação entre ambas. A tese de que a execução das emendas individuais é usada como "moeda de troca" sugere que essa relação seja fruto de uma negociação individual em que o presidente recompensa ou pune os parlamentares de acordo com o seu voto - a favor ou contra o governo (Pereira e Mueller, 2002:274). Se de fato for assim, devemos concluir que a correlação partidária é espúria. Em si mesmos, a filiação partidária não determinaria o comportamento em plenário ou a execução das emendas. Os parlamentares seriam punidos ou premiados individualmente pelo Executivo. Contaria, para isso, o seu comportamento em plenário, independentemente do partido ao que o parlamentar estivesse filiado.

Como se sabe, uma correlação, seja ela expressa por meio de análises de regressão ou por comparação de médias, não é suficiente para demonstrar a existência de uma associação causal entre as duas variáveis. O problema é definir se existe uma relação entre o comportamento em plenário e a execução de emendas que não dependa da filiação partidária. Se encontrarmos baixa execução e baixo apoio apenas entre parlamentares filiados a partidos de oposição, e alta execução e alto apoio apenas entre membros da base do governo, será difícil distinguir entre as explicações calcadas em relações individuais e as determinadas pela 
filiação partidária. Negociações individuais ou centralizadas nos líderes dos partidos levariam a resultados similares. A questão, portanto, é a de distinguir essas duas explicações. Dada a correlação de ambas as variáveis com a filiação partidária, importa distinguir o que pode ser creditado ao partido e o que se deve às negociações individuais. Se encontrássemos casos de deputados filiados a partidos de esquerda com altas taxas de execução e com altas taxas de voto favorável ao Executivo, e/ ou membros da coalizão do governo que votam contra o governo e têm baixas taxas de execução, teríamos fortes evidências favoráveis da hipótese de que as negociações são individuais. Casos como estes indicariam a presença de barganhas individuais, construídas ao largo das filiações partidárias.

Quanto à primeira possibilidade, como mostra o Gráfico 1, não há casos de parlamentares de partidos de oposição que tenham votado sistematicamente com o governo. A variação na taxa de execução é bem maior do que a observada para o apoio ao Executivo. Entre esses parlamentares, a norma é o registro de baixos valores em ambas as variáveis. Ainda assim, podemos verificar alguns poucos casos de execução de média a alta sem a esperada correspondência nas votações nominais - há, até mesmo, deputados com taxa de apoio ao governo nula que tiveram suas emendas integralmente executadas. Podemos concluir desses dados que a liberação de verbas, ao menos entre aqueles deputados filiados a partidos de esquerda, não está associada positivamente à votação em favor do Executivo. Emendas são executadas sem que sejam recebidos votos em contrapartida. Para esse subgrupo de parlamentares, as variáveis apresentam um razoável grau de independência. No entanto, o que definitivamente não ocorreu no período analisado foi o fato de deputados filiados a partidos de esquerda votarem a favor do governo.

Quando passamos a considerar os deputados filiados a partidos que fazem parte da base do governo, como pode ser visto no Gráfico 2, encontramos um número maior de casos que atenderiam aos requisitos do argumento da "moeda de troca", pois há um número considerável de casos com baixo apoio e baixa execução. No entanto, existe um número semelhante de casos em que a execução é alta a despeito do apoio baixo - isto é, há deputados que votaram sistematicamente contra o governo e que tiveram verbas liberadas. Mais inquietante é o acúmulo de casos em que se observa alto apoio e baixa execução. Ou seja, há deputados que têm votação favorável ao Executivo sem que esse retribua 
Processo Orçamentário e Comportamento Legislativo...

\section{Gráfico 1}

Taxa de Execução das Emendas dos Parlamentares de Oposição segundo seu Apoio ao Executivo em Votações Nominais

1996-2001

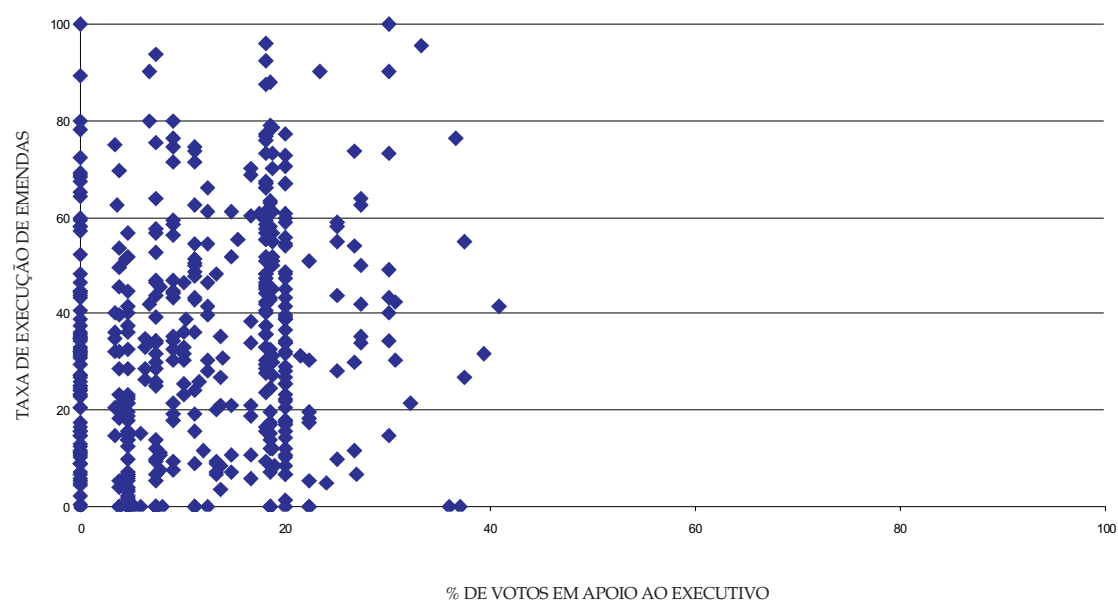

Fontes: Assessoria de Orçamento e Fiscalização Financeira da Câmara dos Deputados, Diário do Congresso Nacional, Banco de Dados Legislativos, Cebrap.

\section{Gráfico 2}

Taxa de Execução das Emendas dos Parlamentares da Base do Governo segundo seu Apoio ao Executivo em Votações Nominais

1996-2001

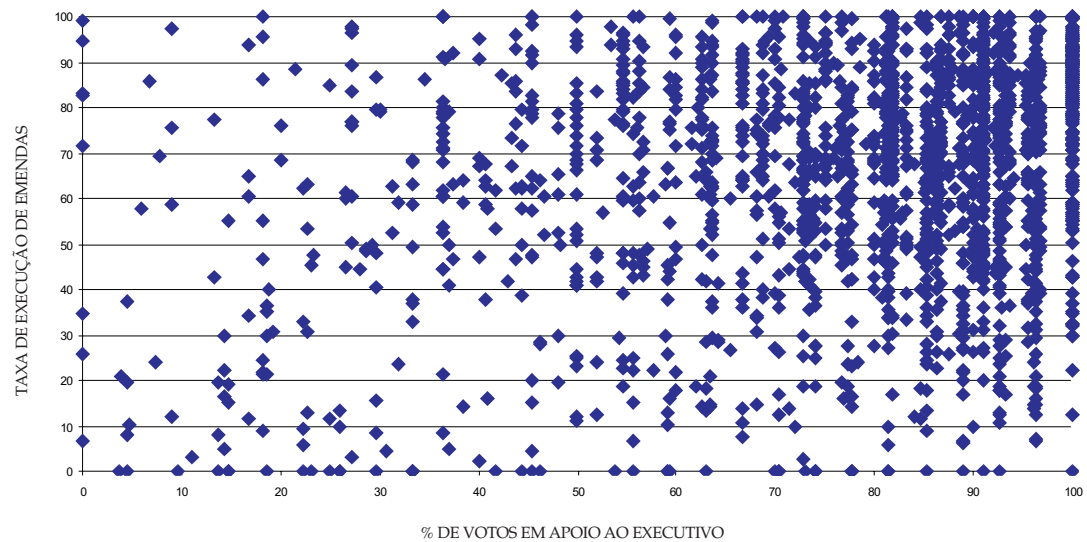

Fontes: Assessoria de Orçamento e Fiscalização Financeira da Câmara dos Deputados, Diário do Congresso Nacional, Banco de Dados Legislativos, Cebrap. 
com a liberação orçamentária. Como esses casos não são excepcionais, podemos concluir que as trocas tão propaladas pela crônica política nacional não constituem o padrão da relação Executivo-Legislativo.

O exame do Gráfico 2 revela a distribuição dos casos por todo o espaço do gráfico. Há, por certo, uma concentração de casos no quadrante superior direito, mas é evidente que a distribuição do apoio ao Executivo é mais homogênea e concentrada em altos valores do que a que se verifica em relação à execução das emendas. Uma vez mais, temos indicações de que o comportamento das duas variáveis segue determinações próprias, e que a filiação partidária possibilita prever com mais acerto qual será o voto dos parlamentares do que o grau de execução das emendas individuais.

A partir da análise dos Gráficos 1 e 2, testamos a hipótese de que a lógica partidária determina tanto o comportamento em plenário quanto a execução de emendas. Essa hipótese pode ser demonstrada recorrendo-se a comparações dos resultados de diferentes modelos de regressão logística (Quadro 1). O primeiro modelo conta com uma única variável explicativa, uma variável dicotômica (uma dummy), que identifica se o parlamentar pertence ou não à base do governo. $\mathrm{O}$ segundo modelo usa a taxa de execução como variável independente. $\mathrm{O}$ terceiro combina os dados dos dois modelos anteriores, isto é, a taxa de apoio ao Executivo é explicada tanto pela filiação partidária quanto pela taxa de execução de emendas.

Nos três modelos, os coeficientes têm o sinal esperado e são estatisticamente significantes, algo perfeitamente previsível para os familiarizados com esse tipo de análise, considerando-se as evidências já apresentadas e o número de casos incluídos na análise. O que se deve comparar é a capacidade explicativa de cada modelo, expressa por sua capacidade de prever o voto dos parlamentares em plenário. Portanto, a comparação deve ter por referência o fato de que os votos que seguem a indicação do Executivo nas votações consideradas representam 60,3\% do total (40.459/67.055). Logo, não é necessário qualquer modelo estatístico para chegar a essa taxa de acerto: basta "chutar" que todos os deputados votarão com o governo, para acertar 60,3\% dos casos.

O primeiro modelo, que conta apenas com a variável que identifica se o parlamentar é membro da base do governo, prevê corretamente $75,36 \%$ dos votos. Já o segundo modelo, cuja variável independente é a taxa de execução das emendas individuais, prevê corretamente $67,86 \%$ 
dos votos. Quando se desconsidera a informação da filiação partidária, a taxa de execução das emendas é, portanto, um preditor inferior dos votos na agenda do Executivo. Essa variável tampouco serve para melhorar significativamente o desempenho do primeiro modelo, uma vez que a diferença entre os resultados alcançados com o primeiro e o terceiro modelo são equivalentes ${ }^{11}$.

Quadro 1

Determinantes do Voto: Agenda do Executivo - Regressões Logísticas

1996-2001

\begin{tabular}{|l|lll|lll|lll|}
\hline Variável Independente & \multicolumn{3}{|c|}{ modelo 1 } & \multicolumn{3}{c|}{ modelo 2 } & \multicolumn{3}{c|}{ modelo 3 } \\
\hline & B & S.E. Sig & B & S.E. Sig & B & S.E. Sig \\
Constante & $-1,54$ & 0,00 & 0,00 & $-0,96$ & 0,00 & 0,00 & $-2,09$ & 0,03 & 0,00 \\
Base do Governo & 2,55 & 0,02 & 0,00 & & & 2,20 & 0,02 & 0,00 \\
Taxa de Execução & 0,026 & 0,02 & 0,00 & & & 0,02 & 0,00 & 0,00 \\
\hline \% Predições Corretas & \multicolumn{2}{|c|}{75,36} & \multicolumn{2}{|c|}{67,86} & \multicolumn{2}{c|}{75,36} \\
\hline
\end{tabular}

\section{$\mathrm{N}=67055$}

* N é fruto da combinação deputado x votação. No entanto, nem todos os deputados votaram em todas as votações. Foram consideradas as mesmas 188 votações incluídas na Tabela 3. Foram considerados apenas os 719 deputados que votaram mais de 10 vezes, que não trocaram de partido ao longo do ano e que apresentaram emendas ao orçamento.

Essas análises indicam que a filiação partidária explica tanto a votação em plenário quanto a execução de emendas. Essa conclusão é reforçada quando consideramos os casos de deputados que votam sem ter emendas a ser executadas e os que têm emendas executadas sem votar. Em ambos os casos, a filiação partidária pode ser usada como variável explicativa. Para sermos mais claros: há um grupo de parlamentares para o qual a tese da "moeda de troca" é, simplesmente, inaplicável. O orçamento é emendado e aprovado em um ano, mas executado ao longo do ano seguinte. Logo, em virtude da flutuação da composição da Câmara dos Deputados, o conjunto de deputados que apresenta e aprova emendas não é o mesmo que exerce mandatos no ano de execução do orçamento. Assim, há deputados que emendam o orçamento e não exercem mandatos (logo, não votam) no ano de sua execução, e há deputados que votam, mas não participaram da elaboração do orçamento e, conseqüentemente, não têm emendas para serem liberadas. Esse último grupo deveria se constituir em um problema para o Executivo. Se a liberação de recursos das emendas individuais é o meio pelo qual o Executivo obtém votos favoráveis à sua agenda, como obter apoio desses parlamentares? Nesses casos, o Executivo careceria do instrumento a que usualmente recorreria para obter apoio. 
Em anos pós-eleitorais, como é o caso, no interior da nossa análise, do ano de 1999, a diferença na composição da Câmara que aprova e naquela que implementa o orçamento é levada a extremos, uma vez que, como se sabe, a taxa de renovação da Casa é relativamente elevada. Do ponto de vista do Executivo, esse deveria ser um ano extremamente difícil na arena legislativa ${ }^{12}$.

Portanto, a comparação do comportamento em plenário dos dois grupos de parlamentares - os que têm emendas a serem executadas, mas não foram reeleitos, e os que não têm emendas a serem executadas por não terem participado da aprovação do orçamento, realizada antes de sua posse - deveria revelar diferenças significativas. Como mostra a Tabela 4, porém, o comportamento dos dois grupos não difere radicalmente. Vale observar ainda que o número de parlamentares com mandato e que não participaram do orçamento é considerável ${ }^{13}$. Isso ocorre, sobretudo, em 1999, início de uma nova legislatura, quando, de um total de 370 parlamentares da base do governo, nada menos do que 154 não tiveram oportunidade de apresentar emendas ao orçamento ${ }^{14}$. Não obstante, esses parlamentares votaram de acordo com suas filiações partidárias. Deputados filiados aos partidos da base do governo seguem a orientação do líder do governo, independentemente de terem ou não emendas a serem liberadas. Quais teriam sido os meios utilizados pelo Executivo para obter esses votos? Se o governo dependesse da liberação de verbas para governar, não poderia ter governado em 1999. Esses dados indicam que as votações em plenário são determinadas pela lógica partidária.

Tabela 4

Percentual Médio de Apoio ao Executivo* por Grupos de Parlamentares e Partidos - Votações Nominais de Emendas Constitucionais 1996-2001

\begin{tabular}{l|l|r|c|c|c|c|c}
\hline \multirow{2}{*}{ Ano } & \multirow{2}{*}{ Partido } & \multicolumn{6}{|c}{ Grupos de Parlamentares } \\
\cline { 3 - 8 } & & \multicolumn{2}{|c}{$\begin{array}{c}\text { Aprovaram Emendas na Lei } \\
\text { Orçamentária }\end{array}$} & \multicolumn{2}{c}{$\begin{array}{c}\text { Não Apresentaram Emendas } \\
\text { na Lei Orçamentária }\end{array}$} \\
\cline { 3 - 9 } & & Média & $\begin{array}{c}\text { Desvio- } \\
\text { Padrão }\end{array}$ & N & Média & $\begin{array}{c}\text { Desvio- } \\
\text { Padrão }\end{array}$ & N \\
\hline \multirow{2}{*}{1996} & GOV & 75,3 & 21,7 & 330 & 76,5 & 21,4 & 63 \\
& ESQ & 14,9 & 12,5 & 77 & 10,6 & 7,7 & 26 \\
& PDIR** & 65,8 & 25,0 & 21 & 87,6 & 7,1 & 2 \\
\hline & Total & $\mathbf{6 4 , 0}$ & $\mathbf{3 0 , 9}$ & $\mathbf{4 2 8}$ & $\mathbf{5 7 , 9}$ & $\mathbf{3 5 , 2}$ & $\mathbf{9 1}$ \\
\hline
\end{tabular}


Processo Orçamentário e Comportamento Legislativo...

Tabela 4

Percentual Médio de Apoio ao Executivo* por Grupos de Parlamentares e Partidos - Votações Nominais de Emendas Constitucionais

1996-2001

(continuação)

\begin{tabular}{|c|c|c|c|c|c|c|c|}
\hline \multirow[t]{3}{*}{ Ano } & \multirow[t]{3}{*}{ Partido } & \multicolumn{6}{|c|}{ Grupos de Parlamentares } \\
\hline & & \multicolumn{3}{|c|}{$\begin{array}{c}\text { Aprovaram Emendas na Lei } \\
\text { Orçamentária }\end{array}$} & \multicolumn{3}{|c|}{$\begin{array}{c}\text { Não Apresentaram Emendas } \\
\text { na Lei Orçamentária }\end{array}$} \\
\hline & & Média & $\begin{array}{l}\text { Desvio- } \\
\text { Padrão }\end{array}$ & $\mathbf{N}$ & Média & $\begin{array}{l}\text { Desvio- } \\
\text { Padrão }\end{array}$ & $\mathbf{N}$ \\
\hline \multirow[t]{4}{*}{1997} & GOV & 80,7 & 21,3 & 347 & 85,7 & 16,6 & 49 \\
\hline & ESQ & 8,7 & 13,8 & 78 & 5,0 & 11,4 & 24 \\
\hline & PDIR $^{* *}$ & 70,8 & 29,7 & 15 & 53,9 & - & 1 \\
\hline & Total & 67,6 & 34,2 & 440 & 59,1 & 40,7 & 74 \\
\hline \multirow[t]{4}{*}{1998} & GOV & 72,0 & 24,9 & 367 & 78,3 & 18,9 & 37 \\
\hline & ESQ & 5,7 & 12,3 & 89 & 2,5 & 4,6 & 9 \\
\hline & PDIR & 62,6 & 29,7 & 13 & 25,0 & - & 1 \\
\hline & Total & 59,1 & 34,7 & 469 & 62,7 & 34,9 & 47 \\
\hline \multirow[t]{4}{*}{1999} & GOV & 74,8 & 19,1 & 216 & 79,5 & 18,3 & 154 \\
\hline & ESQ & 20,9 & 13,1 & 46 & 23,5 & 15,0 & 67 \\
\hline & PDIR & 52,3 & 17,3 & 8 & 42,5 & 23,1 & 12 \\
\hline & Total & 64,9 & 27,3 & 270 & 61,5 & 31,0 & 233 \\
\hline \multirow[t]{4}{*}{2000} & GOV & 77,7 & 20,8 & 379 & 82,5 & 20,3 & 4 \\
\hline & ESQ & 18,0 & 9,7 & 104 & 15,1 & 5,9 & 6 \\
\hline & PDIR & 39,2 & 24,3 & 19 & - & - & - \\
\hline & Total & 63,9 & 31,2 & 502 & 42,0 & 37,0 & 10 \\
\hline \multirow[t]{4}{*}{2001} & GOV & 73,7 & 23,5 & 333 & 72,8 & 30,5 & 27 \\
\hline & ESQ & 14,7 & 8,3 & 93 & 16,4 & 9,6 & 20 \\
\hline & PDIR & 41,9 & 22,0 & 26 & 54,6 & - & 1 \\
\hline & Total & 59,7 & 32,1 & 452 & 48,9 & 36,5 & 48 \\
\hline \multirow[t]{4}{*}{ Total } & GOV & 75,8 & 22,3 & 1972 & 79,2 & 20,1 & 334 \\
\hline & ESQ & 13,4 & 12,5 & 487 & 15,9 & 14,2 & 152 \\
\hline & PDIR & 54,0 & 27,5 & 102 & 48,1 & 25,0 & 17 \\
\hline & Total & 63,1 & 32,2 & 2561 & 59,0 & 34,5 & 503 \\
\hline
\end{tabular}

Fontes: Assessoria de Orçamento e Fiscalização Financeira da Câmara dos Deputados, Diário do Congresso Nacional, Banco de Dados Legislativos, Cebrap.

* Voto favorável a projetos de interesse do Executivo.

** Pequenos partidos de direita.

A situação reversa também deve ser considerada, isto é, a dos parlamentares que têm emendas aprovadas, mas não têm assento na legisla- 
tura quando da execução do orçamento. Se não há votos a obter, seria de esperar que o Executivo não executasse essas emendas. A Tabela 5 compara os dois grupos de parlamentares, mostrando que as taxas de execução de emendas daqueles deputados que estão exercendo mandatos são superiores aos que não se reelegeram. No entanto, a diferença está longe de ser radical. Causa espécie, sobretudo, que as emendas de parlamentares que não votaram uma vez sequer sejam executadas. Para nosso argumento, é essencial notar que as taxas de execução das emendas de deputados que pertencem à base do governo são muito próximas, quer estejam ou não exercendo mandatos. Ou seja, uma vez mais concluímos que as relações partidárias são cruciais para entendermos as relações entre o Executivo e o Legislativo.

Tabela 5

Taxas Médias de Execução de Emendas Individuais em Investimentos, por Grupos de Parlamentares e Partidos

1996-2001

\begin{tabular}{|c|c|c|c|c|c|c|c|}
\hline \multirow[t]{3}{*}{ Ano } & \multirow[t]{3}{*}{ Partido } & \multicolumn{6}{|c|}{ Taxas de Execução Orçamentária } \\
\hline & & \multicolumn{3}{|c|}{$\begin{array}{l}\text { Parlamentares que } \\
\text { Exerciam Mandato }\end{array}$} & \multicolumn{3}{|c|}{$\begin{array}{l}\text { Parlamentares que não } \\
\text { Exerciam Mandato }\end{array}$} \\
\hline & & Média & Desvio-Padrão & $\mathbf{N}$ & Média & Desvio-Padrão & $\mathbf{N}$ \\
\hline \multirow[t]{4}{*}{1996} & GOV & 44,3 & 28,0 & 330 & 41,1 & 23,0 & 13 \\
\hline & ESQ & 15,5 & 18,3 & 77 & 7,0 & 10,0 & 2 \\
\hline & PDIR $^{*}$ & 30,9 & 26,6 & 21 & & & \\
\hline & Total & 38,4 & 28,7 & 428 & 36,5 & 24,6 & 15 \\
\hline \multirow[t]{4}{*}{1997} & GOV & 69,0 & 23,0 & 347 & 51,1 & 25,7 & 40 \\
\hline & ESQ & 47,2 & 20,9 & 78 & 44,1 & 25,4 & 10 \\
\hline & PDIR & 65,5 & 19,1 & 15 & & & \\
\hline & Total & 65,0 & 24,0 & 440 & 49,7 & 25,6 & 50 \\
\hline \multirow[t]{4}{*}{1998} & GOV & 54,4 & 22,3 & 367 & 41,7 & 24,5 & 29 \\
\hline & ESQ & 18,3 & 15,0 & 89 & 30,3 & 8,0 & 3 \\
\hline & PDIR & 53,2 & 17,6 & 13 & 61,3 & 27,8 & 2 \\
\hline & Total & 47,5 & 25,3 & 469 & 41,8 & 23,9 & 34 \\
\hline \multirow[t]{4}{*}{1999} & GOV & 77,4 & 16,0 & 216 & 57,6 & 25,8 & 172 \\
\hline & ESQ & 46,7 & 20,5 & 46 & 42,8 & 26,1 & 52 \\
\hline & PDIR & 67,6 & 27,7 & 8 & 66,5 & 26,3 & 6 \\
\hline & Total & 71,9 & 20,7 & 270 & 54,5 & 26,6 & 230 \\
\hline \multirow[t]{2}{*}{2000} & GOV & 69,1 & 19,9 & 379 & 69,4 & 5,5 & 2 \\
\hline & ESQ & 36,2 & 22,5 & 104 & 25,3 & 12,5 & 2 \\
\hline
\end{tabular}


Processo Orçamentário e Comportamento Legislativo...

Tabela 5

Taxas Médias de Execução de Emendas Individuais em Investimentos, por Grupos de Parlamentares e Partidos

1996-2001

(continuação)

\begin{tabular}{l|l|r|c|c|c|c|c}
\hline \multirow{2}{*}{ Ano } & \multirow{2}{*}{ Partido } & \multicolumn{5}{|c}{ Taxas de Execução Orçamentária } \\
\cline { 3 - 8 } & & \multicolumn{3}{|c}{$\begin{array}{c}\text { Parlamentares que } \\
\text { Exerciam Mandato }\end{array}$} & \multicolumn{2}{c}{$\begin{array}{c}\text { Parlamentares que não } \\
\text { Exerciam Mandato }\end{array}$} \\
\cline { 3 - 8 } & & Média & Desvio-Padrão & N & Média & Desvio-Padrão & N \\
\hline \multirow{2}{*}{2001} & PDIR & 48,3 & 23,7 & 19 & & & \\
\hline & Total & $\mathbf{6 1 , 5}$ & $\mathbf{2 4 , 6}$ & $\mathbf{5 0 2}$ & $\mathbf{4 7 , 4}$ & $\mathbf{2 6 , 7}$ & $\mathbf{4}$ \\
\hline & GOV & $\mathbf{7 9 , 6}$ & 17,0 & 333 & 74,7 & 24,1 & 35 \\
& ESQ & 48,6 & 20,6 & 93 & 48,9 & 25,6 & 16 \\
& PDIR & 68,2 & 19,7 & 26 & 44,8 & 63,4 & 2 \\
\hline \multirow{2}{*}{ Total } & Total & $\mathbf{7 2 , 5}$ & $\mathbf{2 1 , 8}$ & $\mathbf{4 5 2}$ & $\mathbf{6 5 , 8}$ & $\mathbf{2 8 , 4}$ & $\mathbf{5 3}$ \\
& GOV & $\mathbf{6 4 , 9}$ & 24,9 & 1972 & 56,5 & 26,6 & 291 \\
& ESQ & 34,8 & 23,9 & 487 & 42,4 & 25,6 & 85 \\
& PDIR & 54,4 & 26,1 & 102 & 61,1 & 31,5 & 10 \\
\hline & Total & $\mathbf{5 8 , 7}$ & $\mathbf{2 7 , 4}$ & $\mathbf{2 5 6 1}$ & $\mathbf{5 3 , 5}$ & $\mathbf{2 7 , 1}$ & $\mathbf{3 8 6}$ \\
\hline
\end{tabular}

Fontes: Assessoria de Orçamento e Fiscalização Financeira da Câmara dos Deputados, Banco de Dados Legislativos, Cebrap.

* Pequenos partidos de direita.

Tanto as emendas liquidadas sem os correspondentes votos quanto o apoio dado sem a contrapartida da execução de emendas são ocorrências que não podem ser acomodadas nas explicações que procuram no processo orçamentário o elo entre a arena eleitoral e a legislativa. São casos em que, por definição, as trocas postuladas não têm como ocorrer. Em ambos os casos, as variáveis partidárias explicam tanto o apoio ao Executivo quanto a execução das emendas individuais.

Na realidade, a noção de que o apoio legislativo é trocado pela liberação das verbas orçamentárias parte do princípio de que os parlamentares e o Executivo têm, necessariamente, agendas conflitantes. Nesse caso específico, as emendas individuais atenderiam apenas e tão-somente aos interesses dos deputados, e o Executivo liberaria recursos para executá-las somente sob pressão. Parlamentares, de sua parte, só apoiariam o Executivo se recebessem algo em troca.

A divergência entre o Executivo e o Legislativo expressar-se-ia em alocações desiguais de recursos, ditadas pela "conexão eleitoral", isto é, pelos vínculos específicos de cada um dos poderes com o eleitorado. Nesse ar- 
gumento, os legisladores são tratados como se tivessem interesses homogêneos - isto é, como se todos quisessem patrocinar o mesmo tipo de políticas -, que os colocariam em conflito com o Executivo. Esse poder seria o único ator político a ter em mente o interesse geral. Cada parlamentar teria diante de si o seu e apenas o seu eleitorado, o seu reduto. E todos visariam a beneficiar os seus redutos por meio do mesmo tipo de políticas, "entregando" a eles benefícios tangíveis. As emendas individuais seriam os veículos mediante os quais essa estratégia eleitoral se viabilizaria. Nesses termos, a execução de emendas parlamentares é vista como uma concessão do Executivo, que atende os interesses particulares dos parlamentares a fim de obter em plenário, como contrapartida, os votos necessários para aprovar a sua agenda.

No entanto, por que devemos assumir que o Executivo e o Legislativo estão condenados a uma disputa? O fato de os partidos desempenharem um papel nessa relação, ou seja, de existir uma coalizão partidária que apóia o governo e outra que a ele se opõe, nos leva justamente a constatar que os parlamentares não têm interesses homogêneos, quer no que se refere às políticas que preferem, quer no que se refere ao sucesso do governo.

Antes de passarmos à discussão mais aprofundada desse ponto e de suas implicações para a compreensão do papel desempenhado pelas emendas individuais, cabe frisar as conclusões já alcançadas. A relação entre as variáveis estudadas - execução de emendas e apoio ao Executivo na arena legislativa - está longe de ser direta. Claramente, uma variável não explica a outra. Ambas são ditadas por uma causa comum: a posição do partido em relação ao governo. Ainda assim, a filiação partidária não prediz perfeitamente o apoio ou não ao Executivo. O perfil partidário fica mais evidente no caso das votações nominais do que na execução de emendas. O fato é que o Executivo não liquida as emendas individuais como retribuição ao comportamento parlamentar. Da mesma forma, os parlamentares não apóiam o governo apenas quando são recompensados com verbas para suas emendas.

\section{EXECUÇÃO ORÇAMENTÁRIA E PREFERÊNCIAS POLÍTICAS}

Quando cientistas políticos afirmam que os recursos orçamentários são alocados com vistas aos retornos eleitorais dos parlamentares, eles têm em mente um modelo específico de estratégias eleitorais perseguidas pelos políticos. Nesse tipo de argumento, os políticos só se interes- 
sariam por seus mandatos ou cargos. As políticas públicas seriam apenas o meio empregado para alcançarem esse fim. Ou seja, os políticos são office seeking e não policy seeking, para usarmos os termos consagrados pela literatura. Segue dessa premissa que as políticas promovidas por parlamentares serão aquelas que melhor atendam a esse objetivo.

A literatura norte-americana convencionou chamar essa estratégia de "voto pessoal". Os políticos privilegiariam, ao perseguirem essa estratégia, a construção de vínculos personalizados e individualizados com seus eleitores, vínculos cimentados pela provisão de políticas públicas que distribuem bens tangíveis a grupos específicos. Assim, a premissa de que deputados visam à sua reeleição leva à suposição de que todos os parlamentares usarão sua prerrogativa de emendar o orçamento de forma homogênea. Todos usariam as emendas de acordo com o que prevê a "cartilha" da ciência política norte-americana, isto é, promovendo políticas distributivistas para receber em troca votos cruciais que assegurariam a reeleição.

Se todos adotassem esta estratégia, seguiria que os parlamentares já não poderiam ser distinguidos por suas filiações partidárias. Interesses e políticas comuns, distributivas, os uniriam e os colocariam em campo oposto ao do Executivo. Este, em razão da sua conexão com o eleitorado nacional e da necessidade de prestar atenção aos efeitos macroeconômicos dos gastos públicos, seria forçado a levar em conta o interesse geral.

Portanto, nos termos desse argumento, a execução das emendas individuais em nada contribuiria para a implementação do programa do governo. Toda e qualquer emenda individual executada implicaria a subtração de dotações de aplicações preferidas pelo Executivo. Ao executar a emenda de um parlamentar, o Executivo transferiria recursos de suas prioridades para atender os interesses necessariamente parciais e locais dos parlamentares. Não haveria, assim, ganhos a auferir, apenas perdas a computar. Tornando esse ponto mais claro, ainda com o risco de nos tornarmos repetitivos: o Executivo só executaria emendas individuais se forçado a fazê-lo, ou seja, como um meio para obter os votos necessários à a provação da sua agenda legislativa. O Executivo e o Legislativo teriam prioridades mutuamente excludentes.

Essa tese depende ainda de que o Executivo tenha duas agendas, a legislativa e a orçamentária, e que elas sejam suficientemente independentes para permitir que o apoio a uma possa ser compensado pelas 
perdas na outra. Compra-se apoio na esfera legislativa sacrificando-se a agenda orçamentária. A agenda legislativa é tratada como se pertencesse à esfera das escolhas de política, enquanto as decisões referentes ao orçamento são tratadas como transferências de utilidades sem que seja feita uma conexão entre ambas.

Para que esse argumento fosse válido, ou as duas agendas, legislativa e orçamentária, teriam de ser independentes - isto é, as preferências em uma não afetariam as preferências na outra -, ou os atores não perceberiam as inter-relações entre ambas. É difícil crer em qualquer dessas duas alternativas. Como os deputados não perceberiam que a agenda legislativa do Executivo que eles aprovam - por exemplo, a Lei de Responsabilidade Fiscal - tem conseqüências para a liberação de verbas orçamentárias? Ou como acreditar que o Executivo liberaria recursos para pequenos projetos particularistas sem perceber que a soma dessas pequenas benesses geraria déficit e, conseqüentemente, comprometeria a sua agenda de políticas? Achar que o Executivo e o Legislativo vêem a agenda orçamentária de forma independente de sua agenda legislativa é supor que um ou outro, ou ambos, ajam de forma irracional.

Não há trocas entre uma agenda ditada pelos legisladores e outra ditada pelo Executivo. Não há trocas porque não existem duas agendas. Se existem duas agendas, essas são a do governo e a da oposição. Do ponto de vista da execução das emendas individuais, há, na verdade, uma agenda única a considerar: a do governo. As emendas individuais ocupam um lugar restrito no interior dessa agenda, mas, e isto é o que importa para este texto, são parte dessa agenda. Ao executar emendas individuais, o Executivo está implementando a sua agenda, à qual uma parte dos legisladores está associada politicamente, o que inclui, obviamente, a arena eleitoral. É o que discutiremos a seguir.

A prerrogativa de apresentar emendas é uma oportunidade para que o parlamentar participe da alocação de recursos orçamentários, expressando suas prioridades quanto às políticas públicas. No entanto, ainda que contem com uma dotação fixa e assegurada, os parlamentares não expressam suas prioridades sem restrições. A estrutura do orçamento define os programas e atividades passíveis de receberem recursos. Não é possível alocar recursos para programas ou atividades não previstos pelo governo em sua proposta original. Mais importante, se há intenção de ver a emenda executada, o parlamentar deve levar em conta as prioridades do governo, e os legisladores podem saber quais são essas 
prioridades no interior do próprio processo orçamentário. Basta analisar a execução do ano anterior ou a proposta enviada, para conhecer as prioridades do Executivo.

Para além das restrições constitucionais que protegem a proposta enviada pelo Executivo, deve-se considerar ainda a forma como o próprio Congresso organiza a sua participação no processo orçamentário. Conforme discutimos em outros artigos (Figueiredo e Limongi, 2002; 2003), as decisões que realmente afetam - ou podem afetar - o perfil do orçamento são tomadas pelo relator geral e pelos relatores adjuntos. Isto é, a apreciação congressual do orçamento é altamente centralizada e segue linhas partidárias. No que se refere especificamente às emendas individuais - a parte descentralizada do processo -, as dotações para acolhê-las são definidas pelo relator geral no parecer preliminar. Como essas dotações são formadas, em grande parte, pela aplicação de cortes lineares na proposta enviada pelo Executivo, a distribuição das emendas individuais por programas (ou por qualquer outra unidade em que o orçamento seja estruturado) é definida nesse momento ${ }^{15}$. Em uma palavra, os deputados têm poucas opções para decidir como alocar os recursos que lhes são reservados.

Assim, não se nota grande diferença entre os partidos quando as emendas individuais são analisadas tendo em vista a sua distribuição por órgãos responsáveis pela execução assim como pelos programas de governo. A Tabela 6 a seguir apresenta a distribuição das emendas pelas diferentes unidades orçamentárias (em geral, um ministério). As primeiras quatro colunas referem-se à porcentagem do valor das emendas aprovadas por cada um dos grupos de partidos (do governo, de direita e de esquerda) sobre o total. Indicam, portanto, a prioridade que cada grupo político deu a esses órgãos. Comparando-se as entradas para cada um dos grupos de partido, é visível a convergência entre os parlamentares. As prioridades orçamentárias dos membros dos partidos de esquerda não são diferentes daquelas feitas pelos membros da bancada do governo.

As quatro últimas colunas da Tabela 6 trazem as taxas de execução das emendas individuais para cada um dos grupos e órgãos considerados. A comparação linha a linha da tabela revela que o governo favorece os parlamentares de sua base em quase todas as unidades orçamentárias. Há unidades em que essa discriminação é muito inferior à média. É esse manifestamente o caso dos gastos com o Ministério da Saúde 
(Fundo Nacional de Saúde e Fundação Nacional de Saúde), em que as taxas médias de execução das emendas de cada grupo são as mais equilibradas. Vale notar que essas unidades orçamentárias concentram em torno de $20 \%$ dos recursos alocados por meio de emendas individuais. De outra parte, o Ministério do Planejamento, onde se concentram $37,6 \%$ do valor total das emendas individuais, registra forte discriminação política na execução das emendas. Nesse órgão, os parlamentares do governo têm $72,1 \%$ de suas emendas executadas, em contraste com 38,7\% dos parlamentares de oposição. Cabe assinalar, no entanto, que as taxas de execução das emendas dos parlamentares que apóiam o governo dependem fortemente dos totais de execução no órgão.

Tabela 6

Emendas Individuais em Investimentos, por Unidades Orçamentárias e Posição dos Parlamentares

1996-2001

\begin{tabular}{|c|c|c|c|c|c|c|c|c|}
\hline \multirow{3}{*}{ Unidade Orçamentária } & \multicolumn{8}{|c|}{ Emendas Individuais } \\
\hline & \multicolumn{4}{|c|}{$\%$ do Total de Emendas Aprovadas } & \multicolumn{4}{|c|}{$\begin{array}{c}\text { Taxa de Execução* } \\
(\%)\end{array}$} \\
\hline & $\begin{array}{c}\text { Base do } \\
\text { Governo }\end{array}$ & Direita & Esquerda & Total & $\begin{array}{c}\text { Base do } \\
\text { Governo }\end{array}$ & Direita & Esquerda & Total \\
\hline $\begin{array}{l}\text { Ministério do } \\
\text { Planejamento, } \\
\text { Orçamento e Gestão }\end{array}$ & 38,6 & 42,6 & 32,3 & 37,6 & 72,1 & 64,5 & 38,7 & 66,6 \\
\hline $\begin{array}{l}\text { Fundo Nacional de } \\
\text { Saúde }\end{array}$ & 12,1 & 17,3 & 16,1 & 13,0 & 61,6 & 60,5 & 51,2 & 59,3 \\
\hline $\begin{array}{l}\text { Fundação Nacional de } \\
\text { Saúde }\end{array}$ & 7,8 & 7,6 & 6,6 & 7,6 & 69,3 & 54,0 & 63,4 & 67,8 \\
\hline $\begin{array}{l}\text { Ministério da Integração } \\
\text { Nacional }\end{array}$ & 6,8 & 6,8 & 5,0 & 6,5 & 67,9 & 57,6 & 25,0 & 61,6 \\
\hline $\begin{array}{l}\text { Ministério da } \\
\text { Agricultura e do } \\
\text { Abastecimento }\end{array}$ & 6,4 & 4,7 & 5,6 & 6,2 & 74,1 & 55,7 & 24,4 & 65,6 \\
\hline Indesp & 6,0 & 2,9 & 4,4 & 5,6 & 64,6 & 25,5 & 18,0 & 57,4 \\
\hline $\begin{array}{l}\text { Ministério do Meio } \\
\text { Ambiente }\end{array}$ & 5,4 & 4,5 & 3,9 & 5,1 & 56,6 & 56,2 & 43,0 & 54,7 \\
\hline $\begin{array}{l}\text { Fundo Nacional de } \\
\text { Desenvolvimento da } \\
\text { Educação }\end{array}$ & 3,8 & 5,3 & 5,5 & 4,2 & 0,0 & 0,0 & 0,2 & 0,1 \\
\hline $\begin{array}{l}\text { Fundo Nacional de } \\
\text { Assistência Social }\end{array}$ & 2,7 & 2,1 & 4,0 & 2,9 & 68,1 & 32,1 & 17,8 & 54,9 \\
\hline Ministério da Educação & 1,2 & 0,4 & 2,6 & 1,4 & 33,1 & 13,1 & 10,4 & 25,8 \\
\hline DNER & 1,4 & 0,6 & 1,4 & 1,4 & 33,3 & 47,0 & 18,6 & 31,0 \\
\hline
\end{tabular}


Processo Orçamentário e Comportamento Legislativo...

Tabela 6

Emendas Individuais em Investimentos, por Unidades Orçamentárias e Posição dos Parlamentares

1996-2001

(continuação)

\begin{tabular}{|c|c|c|c|c|c|c|c|c|}
\hline \multirow{3}{*}{ Unidade Orçamentária } & \multicolumn{8}{|c|}{ Emendas Individuais } \\
\hline & \multicolumn{4}{|c|}{$\%$ do Total de Emendas Aprovadas } & \multicolumn{4}{|c|}{$\begin{array}{c}\text { Taxa de Execução* } \\
(\%)\end{array}$} \\
\hline & $\begin{array}{l}\text { Base do } \\
\text { Governo }\end{array}$ & Direita & Esquerda & Total & $\begin{array}{l}\text { Base do } \\
\text { Governo }\end{array}$ & Direita & Esquerda & Total \\
\hline $\begin{array}{l}\text { Fundo Nacional de Cul- } \\
\text { tura }\end{array}$ & 0,9 & 0,5 & 1,6 & 1,0 & 69,3 & 40,5 & 59,3 & 66,0 \\
\hline Codevasf & 1,0 & 0,6 & 0,9 & 0,9 & 71,3 & 78,4 & 22,2 & 63,5 \\
\hline Ministério da Cultura & 0,7 & 0,4 & 1,1 & 0,8 & 53,6 & 7,3 & 24,9 & 46,0 \\
\hline Dnocs & 0,6 & 0,1 & 0,8 & 0,6 & 72,2 & 100,0 & 14,4 & 58,7 \\
\hline Embratur & 0,6 & 0,1 & 0,5 & 0,6 & 70,4 & 100,0 & 69,7 & 70,4 \\
\hline Sudene & 0,5 & 1,0 & 0,3 & 0,5 & 49,3 & 24,6 & 59,5 & 48,6 \\
\hline Ibama & 0,4 & 0,5 & 0,8 & 0,5 & 57,1 & 41,4 & 40,9 & 51,9 \\
\hline Demais & 3,1 & 2,1 & 6,6 & 3,7 & 55,6 & 47,6 & 48,1 & 53,1 \\
\hline Total & 100,0 & 100,0 & 100,0 & 100,0 & 64,4 & 55,2 & 37,0 & 59,2 \\
\hline
\end{tabular}

Fontes: Assessoria de Orçamento e Fiscalização Financeira da Câmara dos Deputados, Banco de Dados Legislativos, Cebrap.

* O cálculo da taxa de execução é feito levando-se em consideração o valor das emendas executadas sobre o valor das emendas aprovadas e compreende o total de emendas individuais referentes a investimentos apresentados e liquidados.

O mesmo quadro emerge quando os dados são organizados por programas. As diferenças entre os grupos de partidos são menores do que a convergência entre eles. Observa-se, uma vez mais, que, em todos os programas, as taxas de execução são maiores para os deputados filiados aos partidos que apóiam o governo. No entanto, as diferenças maiores se dão quando se consideram os totais por programas.

Como os dados acima deixam claro, não há divergência maior de agendas entre os parlamentares quando esses são agrupados segundo sua relação política com o Executivo. Isso mostra a capacidade do Executivo e dos relatores de direcionar as emendas individuais para nichos específicos. Os graus de liberdade de que os parlamentares podem dispor são pequenos. A oposição não tem espaço para usar o processo orçamentário a fim de dar vazão à sua agenda.

Os dados mostram também que a execução das emendas individuais é pautada por critérios políticos. As emendas dos deputados filiados a partidos da coalizão do governo têm maiores chances de serem 
Fernando Limongi e Argelina Figueiredo

Tabela 7

Emendas Individuais em Investimentos, por Programas e

Posição dos Parlamentares

1996-2001

\begin{tabular}{|c|c|c|c|c|c|c|c|c|}
\hline \multirow[b]{2}{*}{ Programa } & \multicolumn{4}{|c|}{ \% do Total de Emendas Aprovadas } & \multicolumn{4}{|c|}{ Taxa de Execução* } \\
\hline & $\begin{array}{l}\text { Base do } \\
\text { Governo }\end{array}$ & PDir** & Esquerda & Total & $\begin{array}{l}\text { Base do } \\
\text { Governo }\end{array}$ & PDir* $^{* *}$ & Esquerda & Total \\
\hline Saneamento & 23,5 & 25,0 & 19,8 & 22,9 & 69,2 & 59,8 & 45,2 & 65,1 \\
\hline Saúde & 12,2 & 17,3 & 16,6 & 13,2 & 61,5 & 61,0 & 52,0 & 59,4 \\
\hline Urbanismo & 9,0 & 12,4 & 9,3 & 9,2 & 81,2 & 78,1 & 47,9 & 75,1 \\
\hline Habitação & 9,5 & 9,4 & 7,5 & 9,1 & 74,4 & 68,2 & 40,6 & 69,3 \\
\hline $\begin{array}{l}\text { Programas } \\
\text { Integrados }\end{array}$ & 6,1 & 4,8 & 4,0 & 5,7 & 59,6 & 29,9 & 20,8 & 53,8 \\
\hline $\begin{array}{l}\text { Educação Física e } \\
\text { Desportos }\end{array}$ & 6,0 & 2,8 & 4,5 & 5,6 & 64,9 & 25,5 & 18,4 & 57,6 \\
\hline Recursos Hídricos & 6,0 & 4,8 & 3,5 & 5,5 & 63,8 & 63,1 & 21,5 & 59,1 \\
\hline $\begin{array}{l}\text { Proteção ao Meio } \\
\text { Ambiente }\end{array}$ & 4,4 & 3,9 & 4,0 & 4,3 & 57,8 & 50,7 & 37,2 & 54,2 \\
\hline Energia Elétrica & 4,3 & 3,5 & 3,9 & 4,2 & 75,0 & 60,9 & 28,9 & 67,0 \\
\hline Ensino Fundamental & 3,2 & 4,7 & 4,5 & 3,5 & 0,0 & 2,6 & 0,3 & 0,2 \\
\hline Assistência & 3,4 & 2,1 & 4,2 & 3,5 & 63,3 & 31,4 & 18,7 & 52,9 \\
\hline Cultura & 1,8 & 0,9 & 2,9 & 1,9 & 60,8 & 26,7 & 44,9 & 56,0 \\
\hline $\begin{array}{l}\text { Transporte } \\
\text { Rodoviário }\end{array}$ & 1,4 & 0,6 & 1,3 & 1,4 & 33,6 & 47,0 & 18,6 & 31,2 \\
\hline Segurança Pública & 1,4 & 0,5 & 0,4 & 1,2 & 83,2 & 79,5 & 78,3 & 82,9 \\
\hline Turismo & 1,0 & 0,3 & 1,0 & 1,0 & 61,4 & 18,0 & 56,4 & 59,9 \\
\hline Ensino Superior & 0,6 & 0,4 & 2,1 & 0,9 & 69,8 & 93,2 & 29,6 & 53,0 \\
\hline Ensino Médio & 0,8 & 0,4 & 1,0 & 0,8 & 15,2 & 34,3 & 10,6 & 14,6 \\
\hline Outros & 5,5 & 6,2 & 9,7 & 6,3 & 58,0 & 25,3 & 30,6 & 49,3 \\
\hline Total & 100,0 & 100,0 & 100,0 & 100,0 & 64,4 & 55,2 & 37,0 & 59,2 \\
\hline
\end{tabular}

Fontes: Assessoria de Orçamento e Fiscalização Financeira da Câmara dos Deputados, Banco de Dados Legislativos, Cebrap.

* O cálculo da taxa de execução é feito levando-se em consideração o valor das emendas executadas sobre o valor das emendas aprovadas e compreende o total de emendas individuais referentes a investimentos apresentados e liquidados.

** Pequenos partidos de direita.

executadas do que as dos demais parlamentares. Contudo, parte das emendas de deputados de oposição também são executadas e parte das emendas dos parlamentares que votam com o governo não são executadas. Mais do que isso, nota-se grande variação nas taxas de execução por órgãos e/ ou programas. Em boa medida, essa variação depende dos cortes lineares previstos pelos decretos de contingenciamento. 
Esses cortes - definidos pelo Executivo, obviamente-obedecem às prioridades de políticas públicas estabelecidas por esse Poder.

Pode ser verdade que o apoio parlamentar ao Executivo seja crucial para a execução de sua emenda, mas não como resultado de uma relação de troca referente a cada matéria em votação. A expectativa de ganho do parlamentar na execução de suas emendas depende do partido a que esteja filiado, e é essa filiação que permite prever o seu apoio ao Executivo. Em suma, trocas individuais de apoio por execução de emendas não definem o padrão do gasto público.

\section{CONCLUSÃO}

As emendas individuais não são privilegiadas pelo Legislativo. Os regulamentos internos do Congresso garantem às emendas coletivas e às das relatorias a apropriação da maior parcela dos recursos alocados. Emendas individuais representam uma pequena parcela da intervenção legislativa na alocação final dos recursos (pouco mais de 15\% do total das emendas). E isso ocorre sem a intervenção do Executivo. $\mathrm{Ou}$ seja, como essa é uma decisão interna do próprio Poder Legislativo, tal fato coloca sob suspeição a noção de que o processo orçamentário é orientado basicamente para atender interesses locais ou particularistas de clientelas dos parlamentares.

A despeito disso, dado o papel que normalmente se atribui à liberação de verbas nas relações entre o Executivo e o Legislativo, examinamos a fundo a tese de que votos sejam trocados por execução de emendas, mostrando que não é possível estabelecer a relação causal pretendida. Emendas são executadas sem que os votos esperados sejam dados, e votos são dados sem que a contrapartida, a liberação de verbas, ocorra. A liberação de recursos não explica o comportamento dos parlamentares nas votações nominais. A filiação partidária é um bom preditor da execução das emendas. No entanto, uma inspeção cuidadosa dos dados não permite passar das relações agregadas às individuais. Há deputados de oposição com emendas executadas sem a esperada retribuição em plenário. Há deputados da base de apoio do governo que se comportam "adequadamente" e não vêem os recursos que alocam executados.

Um teste mais direto da existência de uma troca entre liberação de recursos e apoio parlamentar pode ser feito considerando conjuntamente a rotatividade dos membros do Legislativo e o ciclo orçamentário. 
Emendas apresentadas e aprovadas no ano t são ou não executadas em $t+1$. Logo há parlamentares presentes em $t$ que estão ausentes em $t+1$. Fossem as emendas "moedas de troca" e essas emendas não deveriam ter seus recursos liberados. Mostramos que não é isso o que acontece. As taxas de execução das emendas de deputados ausentes, mesmo da oposição, não são nulas. Há ainda o caso dos deputados que tomam posse em $t+1$ sem ter apresentado emendas em $t$. Seria de se esperar que esses deputados "novatos" não apoiassem o Executivo na mesma proporção que o fazem os que apresentaram emendas. O Executivo, nesse caso, não teria "moedas de troca" às quais recorrer para induzir esses parlamentares a votar em favor de sua agenda.

O problema da tese das emendas como "moedas de troca" está em seus supostos. Supõe-se que os legisladores têm um interesse comum, qual seja, o da promoção de políticas distributivistas, uma vez que estas garantiriam (ou afetariam positivamente) suas chances de obter a reeleição. Por extensão, os interesses comuns dos parlamentares são tomados como contrários aos interesses do Executivo. Os dois Poderes estariam imersos em uma relação conflituosa, um jogo de soma zero. Assim, ao executar recursos alocados por emendas individuais, o presidente o faria às expensas de suas próprias prioridades.

Esses argumentos perdem de vista o básico: a principal linha de conflito do sistema político brasileiro não é dada pelas relações entre os poderes, mas sim pelas clivagens político-partidárias. Parlamentares dividem-se em dois grandes campos, os que apóiam e os que se opõem ao Executivo. Essa distinção implica que a maioria apóia a centralização da condução do processo orçamentário em sua fase congressual. Há uma delegação de poder das bases para as lideranças partidárias, nesse caso representadas pelo relator geral e seus colaboradores diretos. Essa delegação explica o papel reduzido que as emendas individuais desempenham na participação do Congresso no processo orçamentário e a importância que as variáveis macroeconômicas assumem para os relatores. Antes de tudo, o orçamento visa a garantir o sucesso da política do governo, especialmente a econômica.

Quanto às prioridades de um e outro poder, expressas na alocação de recursos orçamentários, as diferenças são muito pequenas. Não há agendas conflitantes. Mais especificamente, ao executar recursos alocados por parlamentares mediante emendas individuais, o Executivo não está cedendo a pressões e deixando de executar a sua agenda. A 
alocação de recursos feita pelos legisladores é complementar, e não contrária, à do Executivo. Este é capaz de canalizar as demandas dos parlamentares e acomodá-las no interior dos programas por ele definidos como prioritários. Ao executar emendas de parlamentares da oposição e/ou da situação que não o apóiam, o Executivo está simplesmente executando a sua agenda. O controle do processo pelo Executivo é de tal ordem que nem mesmo os parlamentares da oposição têm como propor emendas que constituam uma agenda alternativa à proposta pelo governo.

A prerrogativa de apresentar emendas individuais ao orçamento é uma oportunidade para que os parlamentares expressem suas prioridades em relação às políticas públicas. No entanto, ainda que contem com uma dotação fixa e assegurada, os parlamentares não expressam suas prioridades sem restrições. O que lhes é permitido, basicamente, é a oportunidade de complementar a agenda definida pelo governo.

(Recebido para publicação em abril de 2005)

(Versão definitiva em novembro de 2005)

\section{NOTAS}

1. Em diversas variantes essa visão pode ser encontrada em Ames (1995a; 1995b; 2001); Bezerra (1999); Pereira (2000a; 2000b); Pereira e Rennó (2001); Pereira e Mueller (2003). As conseqüências desse tipo de conexão na economia são tratadas por Franco (1995) e Serra (1994).

2. O banco de dados utilizado cobre o período posterior à reformulação do processo orçamentário, fruto da Comissão Parlamentar de Inquérito - CPI do orçamento, consubstanciada na adoção da resolução nº 2/1995-CN. Na realidade, em 1994 e 1995, a participação do Congresso no processo orçamentário foi bastante reduzida. Existem dados sobre as emendas individuais para os anos anteriores ao Plano Real, mas é praticamente impossível calcular suas taxas de execução, pois seria necessário que os dados tivessem seus valores corrigidos em relação à inflação, levando-se em consideração o mês de execução da emenda. Os dados relativos a 2002 ainda não se encontravam disponíveis quando da elaboração deste artigo. Sendo assim, o período coberto corresponde ao período para o qual havia dados disponíveis, a fim de que as hipóteses levantadas fossem testadas. As informações relativas à organização dos dados e à operacionalização das variáveis se encontram no Anexo. 
3. Ainda que Comissão Mista de Planos, Orçamento e Fiscalização - CMPOF seja o nome oficial dessa comissão, seu nome é normalmente abreviado para Comissão Mista de Orçamento - CMO. Por ser esse o tratamento convencional, usaremos a forma abreviada no restante do texto.

4. Os dados com os quais trabalhamos foram corrigidos pela inflação e atualizados para valores de 2001. Assim, o teto variou ano a ano. Deve ser observado, ainda, que a consistência que impusemos aos dados fez certas emendas tidas por aprovadas serem desconsideradas em nossa análise. Com isto, alguns parlamentares figuram em nossos dados com valores inferiores ao teto. Note-se ainda que certos parlamentares não fizeram uso da prerrogativa de apresentar emendas individuais. Uma fonte adicional de heterogeneidade na distribuição de recursos por parlamentar deve-se à decisão de trabalhar apenas com as dotações destinadas a investimentos. Ver Anexo, para explicações detalhadas sobre os procedimentos adotados.

5. Cabe observar que em todos os anos analisados o número de parlamentares que tiveram emendas aprovadas foi inferior ao total de 513 deputados. Além dos deputados que têm por norma não apresentar emendas, há casos em que todos os parlamentares de um estado transferiram os recursos de suas emendas individuais para os da bancada estadual. Não é demais notar que esses dois comportamentos não deveriam ser observados se todos os parlamentares adotassem o comportamento individualista e distributivista que a eles se atribui.

6. Não se deve exagerar esse aspecto. A liberdade do Executivo não é completa. Os decretos de contingenciamento definem os cortes por unidades orçamentárias, de acordo com o comportamento das receitas.

7. Ver Figueiredo e Limongi (2002; 2003).

8. Vale observar que os pequenos partidos de direita não parecem receber tratamento diverso do reservado aos grandes partidos que fazem parte da coalizão de apoio ao governo.

9. Votações unânimes foram excluídas. São unânimes as votações em que não há conflito entre os líderes e nas quais a minoria teve menos do que $10 \%$ dos votos.

10. Esse valor discrepa dos encontrados em outras análises (por exemplo, Figueiredo e Limongi, 2000) em razão do critério de construção da amostra e do fato de que as faltas foram tratadas como indisciplina.

11. O mesmo exercício pode ser feito para subamostras com base em critérios diferentes - por exemplo, o grau de conflito da votação - sem que os resultados sofram alteração. Em todos os modelos que testamos, a taxa de execução das emendas contribui menos para a predição do comportamento dos parlamentares. O desempenho dos modelos melhora consideravelmente quando os faltantes são excluídos da amostra. Ainda assim, o desempenho de todos os modelos deixa a desejar. Esse problema decorre da estrutura dos dados, na medida em que as variáveis independentes não variam ao longo de um determinado ano para cada parlamentar. Assim, como a maioria dos parlamentares da base do governo vota favoravelmente ao governo na esmagadora maioria dos casos, o modelo tenderá a prever que todo membro da base deveria ter votado com o governo em todas as votações.

12. Seguindo o mesmo raciocínio, o ano de 1995 também deveria ter sido um ano extremamente difícil para o Executivo. 
13. Os critérios para inclusão desses parlamentares na análise são os mesmos adotados nas análises anteriores.

14. Ainda que as taxas de reeleição não possam ser inferidas desses números, uma vez que licenças e afastamentos também influenciam esse dado, não é demais frisar que baixas taxas de reeleição não deveriam ser observadas se as estratégias eleitorais dos parlamentares fossem bem-sucedidas. A adaptação do modelo norte-americano à realidade brasileira perde de vista esse fato básico. Os livros clássicos de Mayhew (1974) e Fiorina (1989) se baseiam na constatação de que as taxas de reeleição nos Estados Unidos do pós-guerra eram altíssimas.

15. Além dos remanejamentos estabelecidos por esses cortes, as emendas individuais são atendidas por meio de recursos remanejados da Reserva de Contingência e, também, pela reestimativa de receitas.

\section{REFERÊNCIAS BIBLIOGRÁFICAS}

AMES, Barry. (1995a), “Electoral Rules, Constituency Pressures, and Pork Barrel: Bases of Voting in the Brazilian Congress". The Journal of Politics, vol. 57, no 2, pp. 324-343.

. (1995b), "Electoral Strategy under Open-list Proportional Representation". American Journal of Political Science, vol. 39, nำ 2, pp. 406-433.

. (2001), The Deadlock of Democracy in Brazil. Ann Arbor, University of Michigan Press.

BEZERRA, Marcos Otávio. (1999), Em Nome das Bases: Politica, Favor e Dependência Pessoal. Rio de Janeiro, Relume Dumará.

CAIN, Bruce, FEREJOHN, John e FIORINA, Morris. (1987), The Personal Vote: Constituency Service and Electoral Independence. Harvard, Harvard University Press.

FIGUEIREDO, Argelina e LIMONGI, Fernando. (2000), “Presidential Power, Legislative Organization and Party Behavior in Brazil". Comparative Politics, vol. 32, no 2, pp. 151-170.

. (2002), "Incentivos Eleitorais, Partidos Políticos e Política Orçamentária". Dados, vol. 45, no 2, pp. 303-339.

. (2003), “O Legislativo e Âncora Fiscal”, in F. Rezende e A. Cunha (orgs.), O Orçamento e a Transição de Poder. Rio de Janeiro, Fundação Getulio Vargas Editora, pp. 55-91.

FIORINA, Morris P. (1989), Congress: The Keystone of Washington Establishment. New Haven, Yale University Press.

FRANCO, Gustavo Henrique Barroso. (1995), O Plano Real e outros Ensaios. Rio de Janeiro, Francisco Alves.

MAYHEW, David. (1974), The Electoral Connection. New Haven, Yale University Press. 
PEREIRA, Carlos. (2000a), What Are the Conditions for the Presidential Success in the Legislative Arena? The Brazilian Electoral Connection. Tese de Doutorado, New School University, New York.

. (2000b), “Why Have Brazilian Legislators Decided to Clean up their Sidewalks? The Influence of the Brazilian Political Institutions on the Process of State Reform", in S. Nagel (ed.), Handbook of Global Political Policy. New York, Marcel Dekker, Inc.

e RENNÓ, Lúcio. (2001), “O que É que o Reeleito Tem? Dinâmicas Político-Institucionais Locais e Nacionais nas Eleições de 1998 para a Câmara dos Deputados". Dados, vol. 44, no 2, pp. 323-362.

PEREIRA, Carlos e MUELLER, Bernardo. (2002), “Comportamento Estratégico em Presidencialismo de Coalizão: As Relações entre Executivo e Legislativo na Elaboração do Orçamento Brasileiro". Dados, vol. 45, no 2, pp. 265-301.

. (2003), “Partidos Fracos na Arena Eleitoral e Partidos Fortes na Arena Legislativa: A Conexão Eleitoral no Brasil". Dados, vol. 46, no 4, pp. 735-771.

SANTOS, Maria Helena de Castro, MACHADO, Érica Massimo e ROCHA, Paulo Eduardo Nunes de Moura. (1997), “O Jogo Orçamentário da União: Relações Executivo-Legislativo na Terra do Pork-Barrel", in E. Diniz e S. Azevedo (orgs.), Reforma do Estado e Democracia no Brasil. Brasília, Editora da UnB/ENAP.

SERRA, José. (1994), O Orçamento no Brasil: As Raízes da Crise. São Paulo, Atual Editora. 


\section{LISTA DE SIGLAS}

Codevasf - Companhia de Desenvolvimento dos Vales do São Francisco e do Paraíba

DNER - Departamento Nacional de Estradas de Rodagem

DNOCS - Departamento Nacional de Obras contra as Secas

Embratur - Instituto Brasileiro do Turismo

Ibama - Instituto Brasileiro do Meio Ambiente e dos Recursos Naturais

Renováveis

Indesp - Instituto Nacional de Desenvolvimento do Desporto

PC do B - Partido Comunista do Brasil

PDT - Partido Democrático Trabalhista

PFL - Partido da Frente Liberal

PHS - Partido Humanista da Solidariedade

PL - Partido Liberal

PMDB - Partido do Movimento Democrático Brasileiro

PMN - Partido da Mobilização Nacional

PPB - Partido Progressista Brasileiro

PPS - Partido Popular Socialista

Prona - Partido da Reedificação da Ordem Nacional

PSB - Partido Socialista Brasileiro

PSC - Partido Social Cristão

PSD - Partido Social Democrático

PSDB - Partido da Social Democracia Brasileira

PSL - Partido Social Liberal

PST - Partido Social Trabalhista

PSTU - Partido Socialista dos Trabalhadores Unificado

PT - Partido dos Trabalhadores

PTB - Partido Trabalhista Brasileiro

PTN - Partido Trabalhista Nacional

PV - Partido Verde

Sudene - Superintendência do Desenvolvimento do Nordeste 


\section{ANEXO \\ Procedimentos Utilizados para a Reorganização do Banco de Dados do Orçamento Geral da União}

A fonte das informações utilizadas neste artigo é o banco de dados Execução Orçamentária da União, que a Assessoria de Orçamento e Fiscalização da Câmara, juntamente com o Centro de Informática e Processamento de Dados do Senado Federal - Prodasen, elabora e disponibiliza no site da Comissão Mista de Orçamento e Fiscalização. Esse banco de dados foi reorganizado para a finalidade específica desta pesquisa, ou seja, a de distinguir nos valores consignados para a menor unidade de dotação orçamentária (RUBRICA) a alocação de recursos realizada pelo Executivo e pelo Legislativo na Lei Orçamentária Anual - LOA e no orçamento executado.

Os dados contidos nos bancos originais permitem o acompanhamento das diferentes fases do processo orçamentário, a saber, o Projeto de Lei Orçamentária - PLO enviado pelo Executivo, as emendas aprovadas pelo Legislativo (EME), o projeto aprovado, os vetos presidenciais (VETOS), a LOA, conforme sancionada pelo presidente, e, finalmente, os montantes liquidados (LIQ), após os remanejamentos, indisponibilidades e suplementações, que alteram parcial ou totalmente o valor consignado a cada rubrica na LOA.

A RUBRICA é uma combinação única das seguintes classificações orçamentárias: Unidade Orçamentária - UO, Função, Programa, Subprograma, Projeto-Atividade, Subprojeto-Atividade. No banco que organizamos, distinguimos também as rubricas pela Natureza da Despesa (GND). Os bancos construídos para cada um dos anos considerados contêm, em média, 15 mil registros, os quais correspondem à combinação única de rubricas e grupos de despesas (GND).

O primeiro tratamento dispensado teve por objetivo assegurar a consistência interna dos dados. Para tanto, tomamos, como referência, os valores contidos no orçamento aprovado (LOA). A consistência requerida significou condicionar, do ponto de vista das emendas aprovadas (EME) pelo Congresso, a incorporação dessas à existência da dotação correspondente na LOA. Quando o valor da emenda excedeu o que constava da LOA, ele foi corrigido. O valor máximo admitido para as emendas do Congresso em uma determinada RUBRICA/GND é igual ao valor da LOA. Assim, em nosso banco, o valor original das emendas 
(EME) foi revisado, formando uma nova variável que chamamos de EMER. Note-se que poderíamos ter adotado o procedimento inverso: corrigir a LOA com base nas informações relativas às emendas. Se fosse essa a opção, elevaríamos a participação inicial do Congresso no orçamento aprovado, mas reduziríamos sensivelmente sua participação nos valores executados, isso porque, em geral, emendas sem correspondência na LOA não são executadas, ou seja, há fortes indicações de que, de fato, se trata de erro nos registros.

Houve um problema adicional a resolver nessa operação decorrente do fato de os dados para emendas, exceção feita a 1999, não contarem com o identificador do GND. Como a grande maioria das rubricas só conta com um GND, sua atribuição às emendas é, nesses casos, uma operação trivial. Recorremos a rotinas (programas) para fazer a atribuição "mecânica" a partir de regras lógicas que buscam maximizar a correspondência entre os dados e minimizar as correções necessárias. Em casos mais complexos, uma emenda precisou ser subdividida em mais de uma RUBRICA/GND. Sabemos que a maioria dos gastos definidos pelo Congresso se destina a investimentos, $\mathrm{GND}=4$, mas precisávamos garantir que esse conhecimento estabelecido respeitasse a consistência interna dos dados.

Construímos, assim, bancos de dados paralelos e integrados para as emendas aprovadas pelo Legislativo a cada ano. Nesses bancos, a unidade de referência não é a RUBRICA/GND, mas sim a emenda, à qual atribuímos uma RUBRICA/GND. Cabe notar que uma RUBRICA/GND pode ser objeto de mais de uma emenda. Para 1996, o banco de emendas conta com 5.100 registros. Há um acréscimo significativo de emendas nos três anos seguintes, quando o banco de emendas passou a contar com uma média de 8.500 registros.

Dispondo de dados consistentes sobre a dotação inicial aprovada (LOA) e sobre o valor dessas que pode ser atribuído às emendas (EME), pudemos deduzir, por mera subtração, o valor da proposta enviada pelo Executivo que consta da LOA, isto é, LOA-EMER=PLOR. PLOR é a parte aprovada do Projeto de Lei Orçamentária enviado pelo Executivo. Atribuindo ao Executivo a proposição de todas as dotações que não são originárias de emendas, garantimos a consistência interna dos dados no nível de desagregação adequado à análise. Esse procedimento desconsidera as informações contidas no banco original relativas ao projeto enviado inicialmente pelo Executivo (PLO). Isto é, não compa- 
ramos o que o Executivo enviou com o que foi aprovado. Tomando a LOA como referência, não temos como distinguir, no PLO, o que constitui erro dos cortes impostos pelo Legislativo. Trabalhamos, portanto, com uma decomposição do que foi aprovado na LOA, diferenciando as dotações que se deveram à iniciativa do Legislativo daquelas que podem ser creditadas à proposta original do Executivo. Cabe notar ainda que a proposta do Executivo incorpora os gastos dos órgãos que têm autonomia orçamentária, como o Judiciário e o Legislativo.

O banco de dados original acompanha as diversas modificações por que passou o orçamento ao longo do ano. As informações relativas a cortes, remanejamentos e créditos adicionais foram resumidas e computadas em uma única variável, suplementações (SUP). Isso foi feito, novamente, para cada RUBRICA/GND, de forma a obter o saldo dessas operações, ou seja, a dotação autorizada (AUT). Assim, para cada unidade do banco, a regra seguida é a de que LOA+SUP=AUT. Vale notar que o valor de SUP não é necessariamente positivo. AUT pode ser obtido pela operação EME+PLO+SUP, dado que LOA=EMER+PLOR.

Por último, acompanhamos a execução orçamentária para cada RUBRICA/GND. Para garantir a consistência dos dados, corrigimos esses valores de tal forma que eles não excedessem o valor autorizado. Feito isso, a variável que indica o valor executado (LIQ) pôde ser decomposta em três partes, que formam toda e qualquer dotação com gastos autorizados. Como uma RUBRICA/GND pode contar com aportes dos três diferentes momentos identificados, foi necessário estabelecer a ordem em que gastos foram liquidados. Optamos por privilegiar a execução das verbas consignadas pelo Congresso, isto é, a execução liquida primeiro os gastos de EME até seu limite máximo. Restando saldo a liquidar na RUBRICA/GND, passamos à liquidação dos gastos propostos pelo Executivo, respeitado seu limite máximo. A operação foi repetida para os valores suplementados. Temos assim que LIQ=LIQEME+LIQPLO+LIQSUP, respeitadas as restrições óbvias de que é possível efetuar gastos sem autorização, ou seja, é sempre verdade que LIQEME <=EMER, LIQPLO $<=$ PLOR, LIQSUP $<=$ SUP. Garantimos, dessa forma, consistência interna aos dados, evitando dupla contagem.

Uma vez calculado o valor de LIQEME, pudemos retornar ao banco de emendas para distribuir os valores liquidados por cada emenda aprovada. Para os casos em que existia apenas uma emenda aprovada para 
uma RUBRICA/GND, a operação não acarretou problemas. Quando mais de uma emenda contribuiu para a dotação em uma RUBRICA/GND, calculamos a contribuição proporcional de cada uma delas para o valor total das emendas aprovadas naquela RUBRICA/GND e impusemos uma participação relativa análoga ao valor executado. Assim, se uma emenda contribuiu com $50 \%$ da dotação aprovada, atribuímos a essa mesma emenda 50\% dos valores executados. Esse procedimento visa a evitar a dupla contagem, garantindo que o total de valores executados no banco de emendas seja igual ao obtido na RUBRICA/GND.

Cabe notar, para finalizar, que os dados por nós organizados de forma a garantir a consistência interna no nível mais desagregado possível apresentam diferenças marginais dos dados apresentados de forma agregada por órgãos, programas etc. nos diferentes sites do governo e do Legislativo. 


\begin{abstract}
The Budget Process and Legislative Behavior: Individual Amendments, Support for the Executive Branch, and Government Programs
\end{abstract}

The article challenges the contention that individual amendments are crucial for a system of exchanging favors with the Administration by members of Congress interested in distributive policies as a way of guaranteeing their reelection. By analyzing funds allocated through Congressional amendments, their distribution in different government programs, and roll-call votes in the Brazilian House of Representatives from 1996 to 2001, the authors show that: individual amendments are not prioritized either by Congress in the budget's approval or by the Administration in its implementation; there are no differences between the agenda dictated by the Administration and that of the legislators; and party affiliation explains both House floor votes and the implementation of individual amendments and is thus an explanatory variable in the Executive-Legislative relationship.

Key words: budget; Executive Branch; Legislative behavior; budget amendments

\title{
RÉSUMÉ
}

Mécanismes Budgétaires et Comportement Législatif: Amendements Individuels, appui au Pouvoir Exécutif et Programmes de Gouvernement

Dans cet article, on s'oppose à la thèse selon laquelle les amendements individuels sont fondamentaux pour un système d'échanges d'appui au gouvernement de la part de parlementaires aspirant à des politiques distributives comme l'une des formes de garantir leur réélection. À partir de l'analyse des ressources qui ont été attribuées par la voie d'amendements parlementaires, de leur distribution dans les différents programmes gouvernementaux et du vote nominal à la Chambre des Députés entre 1996 et 2001, on montre ici que les amendements individuels ne sont pas privilégiés par le pouvoir législatif lors du vote du budget, ni par le pouvoir exécutif lors de son exécution; il n'y a pas de différences entre un programme dicté par l'exécutif et le programme des législateurs; l'affiliation aux partis peut expliquer non seulement les votes à la Chambre mais aussi l'exécution des amendements individuels, ce qui en fait une variable-clé pour expliquer la relation Exécutif-Législatif.

Mots-clé: budget; pouvoir exécutif; comportement législatif; amendements budgétaires 